Jpn. J. Med. Mycol.

Vol. 44, 163-179, 2003

ISSN $0916-4804$

総説

接合菌症：2症例の報告および本邦報告例の検討

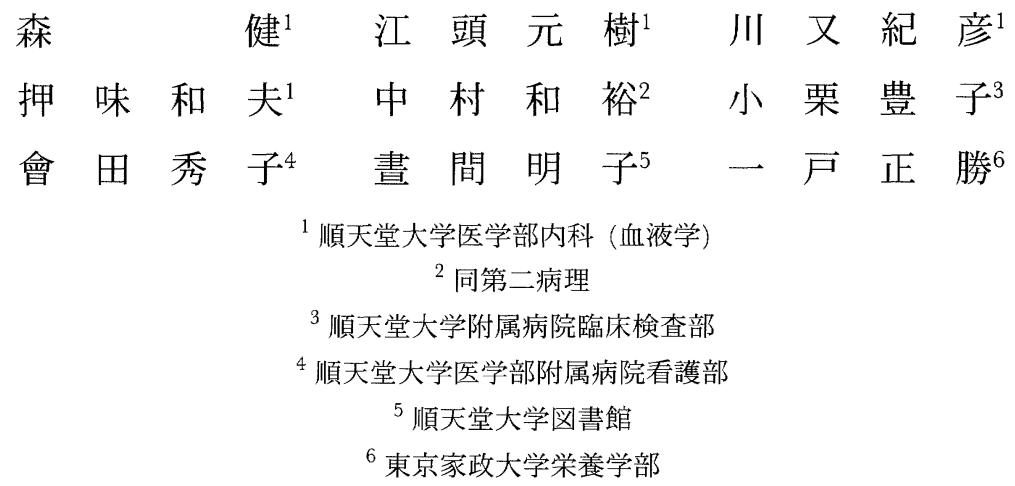

要 旨

最近経験した接合菌症 2 例と本邦報告例を集計し検討した結果を報告する. 症例 1 （43歳・男性）は悪性リンパ腫 の治療経過中に肺炎・脳出血を併発し死亡した. 剖検では接合菌による肺病変が認められた. 脳病変の検索は出来な かったが, 接合菌の関与が強く疑われた. 症例 2 （52歳・男性）は急性リンパ性白血病の治療中に発熱し，胸部X線 上両肺に異常陰影を認め, 喀痰培養で Cunninghamella elegans を 4 回検出し, itraconazole および amphotericin B (AMPH) の併用療法を開始し，後に AMPH liposomal AMPH に変更したが肺病変は完全には消失しなかった. その後末梢血幹細胞移植のため前処置開始後に高熱を認め, 血液培養で Staphylococcus epidermidis が検出され抗生剂を 変更したが, 白血球数が回復しないまま肺炎を併発して死亡した. 剖検は行えなかった. 本邦では 1907 年の稲田の報 告以降 204 例（病型不明 1 例を含む）が報告されている. 鼻脳型は 55 例で, 基礎疾患のない症例が 29 例, 生前診断例 34 例, 死亡例は 24 例であった. 肺・播種性病変などを含む組織侵襲性病変は 144 例で, 白血病が 66 例を占め, 生前診 断例 39 例, 死亡例は 120 例であった. ムーコル喘息 5 例の予後は良好であった. 鼻脳型では手術例や排膿を行った症 例，その他の組織侵襲性病変では切除例で予後は良かった. 真菌が分離・同定された症例は 14 例にすぎなかった. 本 症に対しては積極的な検索・治療が望まれる.

key words: zygomycosis, diagnosis, treatment, prognosis, clinical analysis.

はじめに

接合菌は穀類・果物・野菜などに腐生する所謂「ケ力 ビ」であり，自然界に広く分布する真菌である. 分類学上 Class (綱) Zygomycetes は Order (目) Mucorales と Order Entomophtorales に分類され, Order Mucorales はさらに Family (科) Cunninghamellaceae, Family Mortierellaceae, Family Mucoraceae, Family Sakenaeaceae, Family SyncephalastraceaeおよびFamily Thamnidiaceaeに分 けられている11. 臨床的には Family Cunninghamellaceae と Family Mucoraceaeが主な日和見感染症の原因であ る.

今回は自験例 2 例および本邦で報告された Family Mucoraceae (Absidia, Mucor, Rhizomucor, Rhizopus) 及び Family Cunninghamellaceae (Cunninghamella) による感

別刷請求先 : 森 健

干113-8421 東京都文京区本郷2-1-1

順天堂大学医学部内科（血液学）
染例を集計した結果に就いて述べる. なお皮膚病変及び 極めて稀な Order Entomophtorales 感染症については集 計から除いた。

\section{症例}

最近経験した 2 症例を呈示する.

症例 $1: 43$ 歳の男性. 平成 12 年 3 月 10 日に入院され, NKlike cell lymphoma の診断のもとに治療を開始した. PACC 療法 (prednisolone [PSL], cytarabine, cyclspoine [CPA], cisplatin) を 3 クール, CHOP 療法 (PSL, CPA, adriamycin, vincristin) を2クール行ったものの, 著明な改 善は認められなかつた. 化学療法後の白血球減少に伴い 発熱を繰り返したが, 入院時より胸部 X線上感染を思わ せる異常所見は見られなかった.9月13日からはCPA， PSL による内服治療に変更した. しかし各種デー夕から 肝・脾・骨髄にまで lymphoma の浸潤が及んでいると 考えられ，9月中旬以降は 2 日に 1 回，血小板輸血が必 要な状態であった.9月末より高熱が出現したにも拘わ 


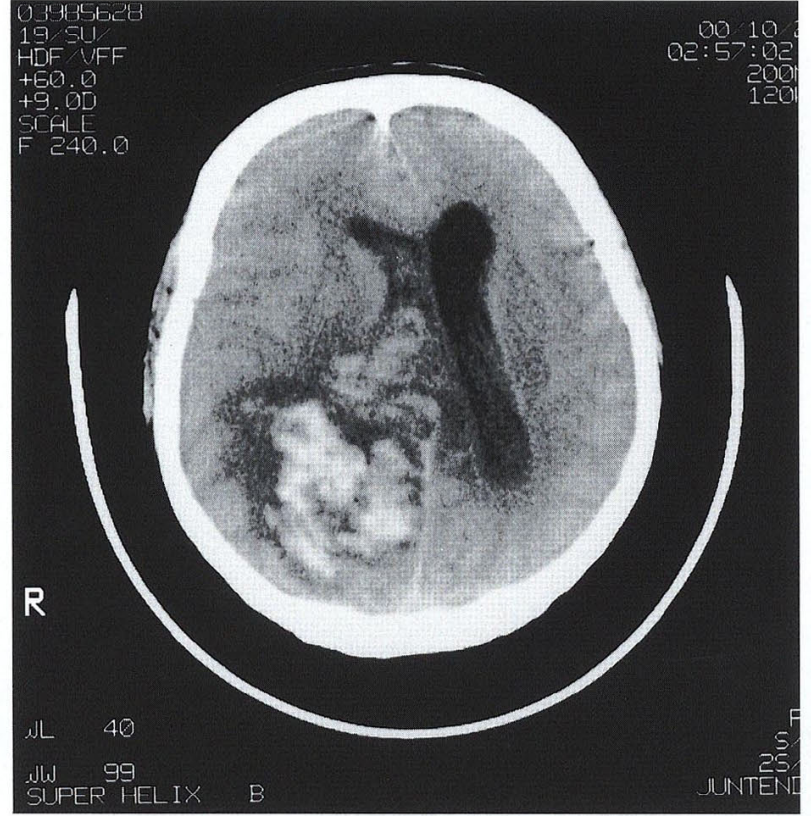

Fig. 1. CT-scan of head of Case 1 showed cerebral hemorrhage.

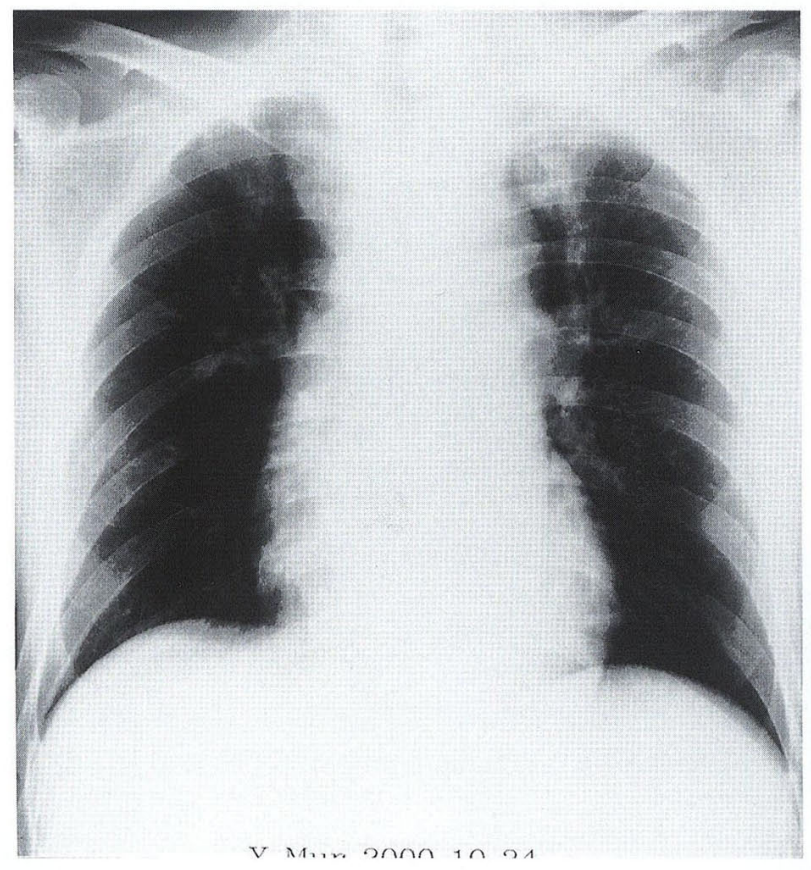

Fig. 2. Chest X-ray finding of Case 1 on the day of his death.

らず，胸部 X線像で異常は認められなかった.しかし顆 粒球減少が granulocyte colony-stimulating factor [G-CSF] 投与に反応しないまま, 高熱・中枢神経系症状が出現 し, 頭部 CT-scan（Fig. 1) で脳出血像と診断された. また死亡当日の胸部 X線では左肺尖部に梗塞像を思わ せる楔状陰影を認め (Fig. 2), 最後は脳内出血および敗 血症のため10月24日に死亡. なお死亡 3 日前および 2 日 前の血液培養で Enterococcus faecium, E. gallinarum が共に 陽性であったことが死亡後に判明した.

病理解剖では,

1. 悪性リンパ腫 (diffuse large B cell type, 化学療法 後の状態): 脾の構造は破壊され, 大型の異型性の強いリ

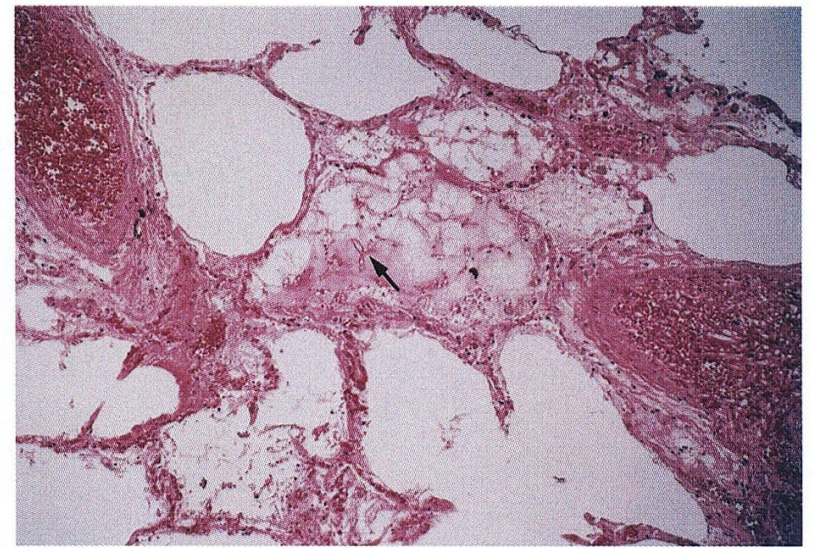

Fig. 3. Pathological finding showed fungal elements in the alveolar space. (arrow) (PAS staining, $\times 200$ )

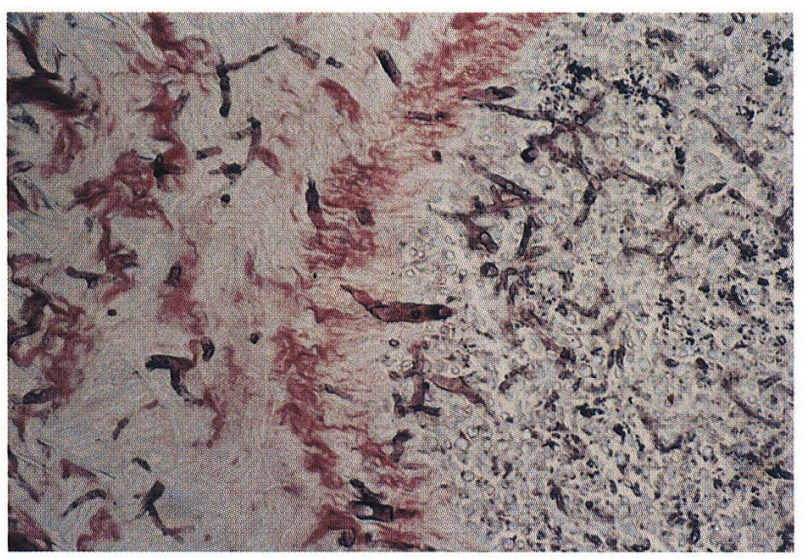

Fig. 4. Pathological findings showed fungal elements in the blood vessel and invading the blood vessel wall. (Methenaminesilver stain, $\times 400$ )

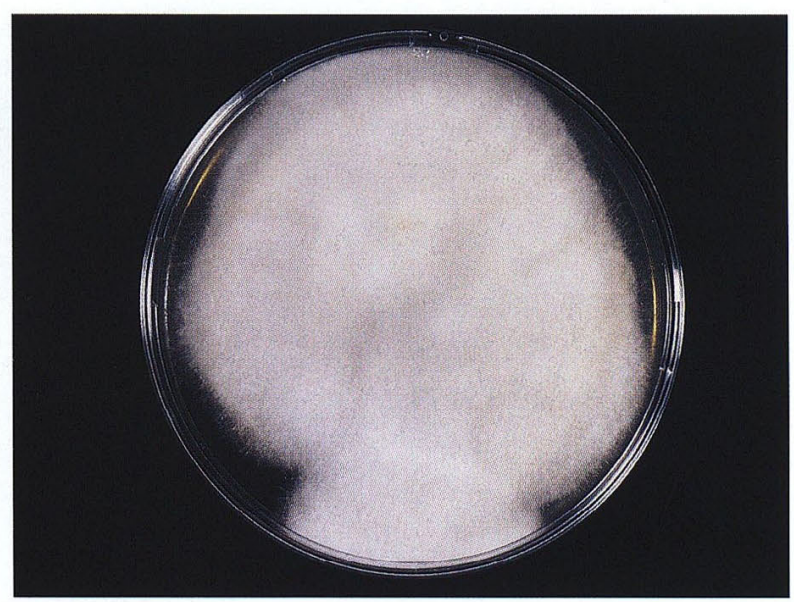

Fig. 9. Macroscopic finding of culture of Cunninghamella elegans on Sabouraud glucose agar.

ンパ腫細胞により置換されており, 免疫染色では大型で 異型性の強いリンパ細胞は L26 陽性で, UCHL1, CD3, NK1 は背景のリンパ球のみ陽性であった. リンパ腫細 胞は内皮下に高度に浸潤していた. その他リンパ節・肝 ・骨髄・睪丸など全身に悪性リンパ腫の所見を認めた。

2. 盲腸粘膜壊死 : 盲腸粘膜の壊死部に多数のグラム陽 


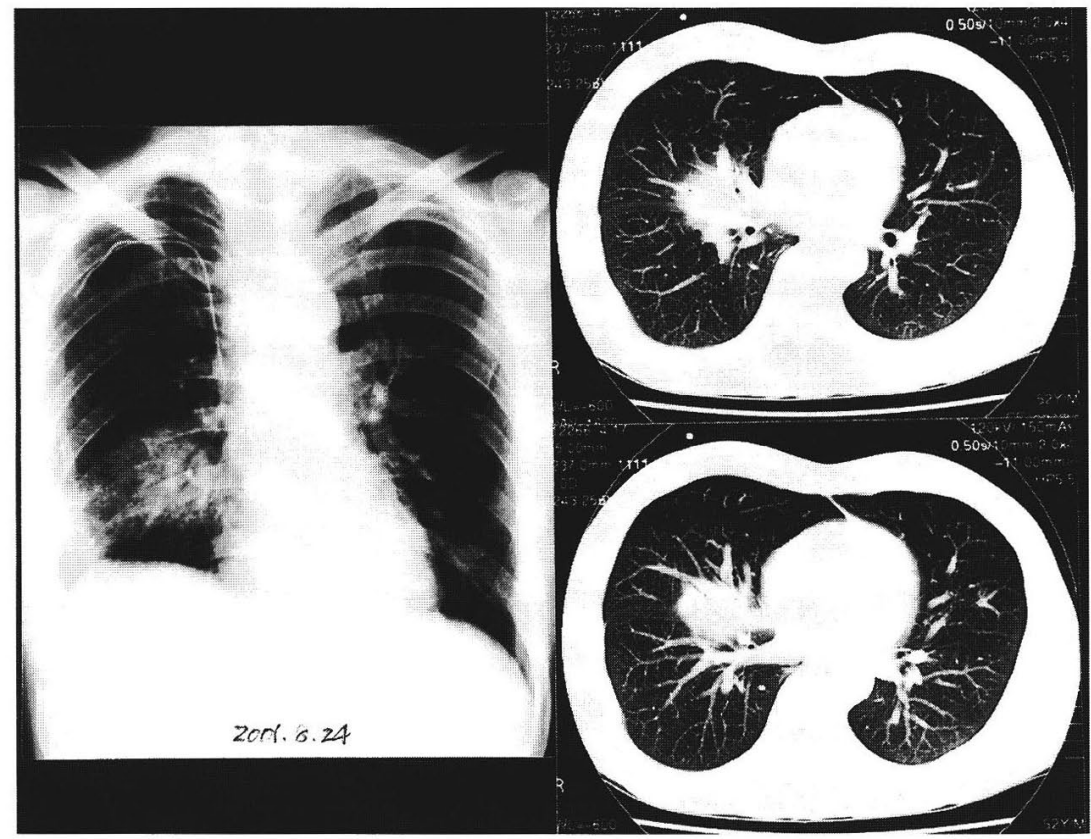

Fig. 5. Chest X-ray and CT-scan findings of Case 2 on the 7th day hospitalized.

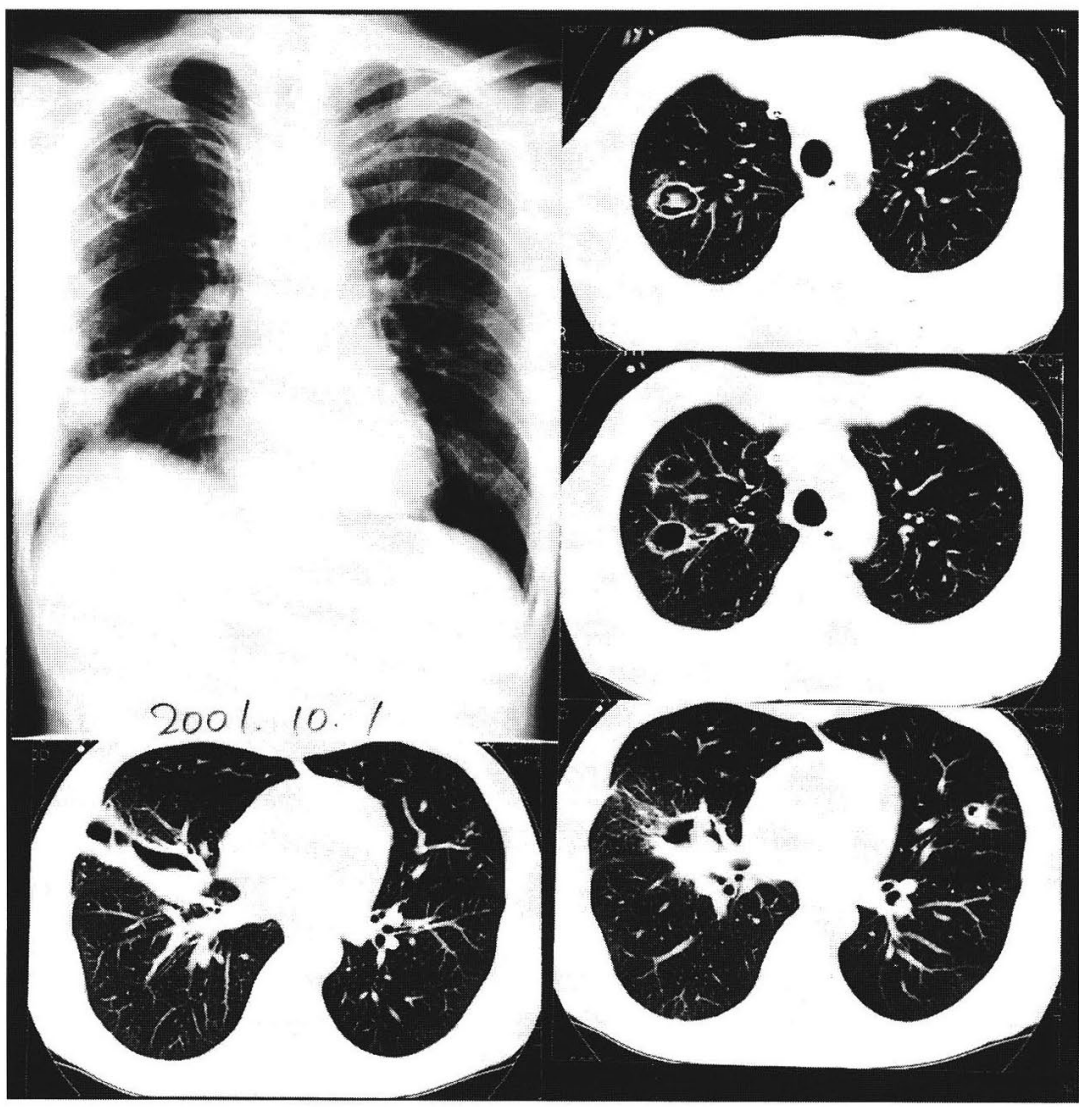

Fig. 6. Chest X-ray and CT-scan findings of Case 2 on the 76th hospitalized day showed bilateral shadows.

性球菌・桿菌およびグラム陰性球菌・桿菌が見られた. 3. 左肺上葉にムーコル (Fig. 3，4）およびグラム陽性 球菌による感染巣が認められた.

頭部の解剖は行われていないため, 死因となった脳内 出血の原因は不明であるが, ムーコルの関与が強く疑わ れた。
症例 $2: 52$ 歳の男性. 平成 13 年 7 月 22 日全身倦怠感・易 疲労感を認め，2 日後に出張先のパリで悪寒・全身の疼 痛を自覚し，3 日後（帰国後の27日）には $38^{\circ} \mathrm{C} の$ 発熱が 出現し持続した. 29日に近医を受診し抗生剤を投与され るも改善せず，血液検査の結果急性白血病を疑われ，8月 4 日近くの病院へ入院. 精査の結果, 急性リンパ性白血 


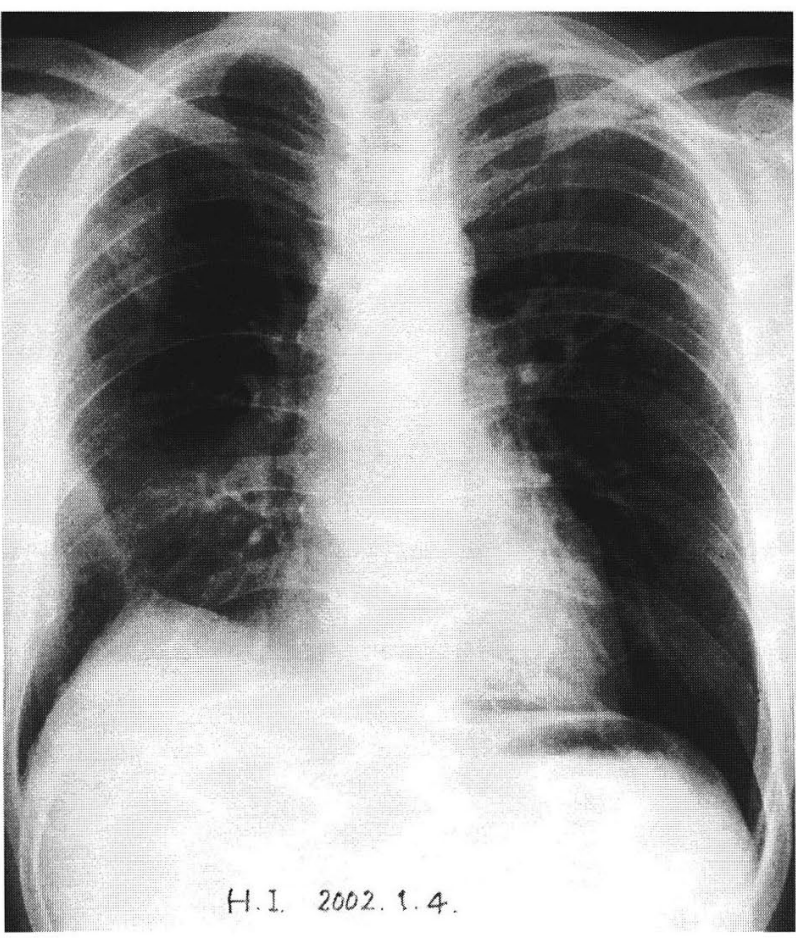

Fig. 7. Chest X-ray findings of Case 2 on the 140th hospitalized day.

病 [L2] と診断され, JALSG-ALL97 プロトコールに従 い寛解導入療法が開始されたが, 本人の希望により我々 の病院へ 8 月 17 日転入院された. 転入院後 itraconazole (ITCZ) $200 \mathrm{mg} /$ 日の内服を行っていたが発熱は持続し， $\mathrm{X}$ 線像上右肺に異常陰影を認めると共に（Fig. 5)，8 月 25，30，31日および 9 月 4 日の 4 回, 喀痰から Absidia sp. （後にCunninghamella elegans と判明）を検出した. そこ で amphotericin B (AMPH) $50 \mathrm{mg}(0.74 \mathrm{mg} / \mathrm{kg}) /$ 日の点 滴静注に変更し, 後に ITCZの併用を行つた. 途中尿素 窒素 (BUN), クレアチニン $(\mathrm{Cr})$ の上昇などの腎障害を 認めたため, liposomal amphotericin B (AmBisome) の 点滴静注に変更し, $50 \mathrm{mg}(0.74 \mathrm{mg} / \mathrm{kg}) /$ 日から始め, 次 いで $75 \mathrm{mg}(1.1 \mathrm{mg} / \mathrm{kg}) /$ 日その後 $100 \mathrm{mg}(1.47 \mathrm{mg} / \mathrm{kg}) /$ 日に増量し, ITCZの併用は続行した. その結果, 解熱傾 向を認め, 胸部 X 線上両肺に拡がっていた陰影（Fig. 6) も徐々に縮小したが, 完全には消失しなかった. Cunninghamella 感染症があるため, 基礎疾患に対して化 学療法・骨髄移植（BMT）などを含む強い治療が行え ないまま, imatinib を投与し胸部 X 線像は改善傾向を 認め小康状態を保っていた. しかし幼若細胞が消失せず BMTなどによる治療が必要であり, そのため感染巣の 切除も検討されたが, 病巣が両側肺にあることより, 手 術の適応ではないと考えられた. その後胸部 X 線上の陰 影がある程度縮小したことを考慮し（Fig. 7), 結局末梢 血幹細胞移植（PBSCT）を行うことになり, PBSCTの 前処置を開始した. 前処置開始後に高熱を認め, 2 月 21 日（死亡14日前）の血液培養で Staphylococcus epidermidis を検出した. 抗生剂を変更したが効果なく, 白血球減少 が回復しないまま右肺炎 (Fig. 8) を合併して 3 月 5 日

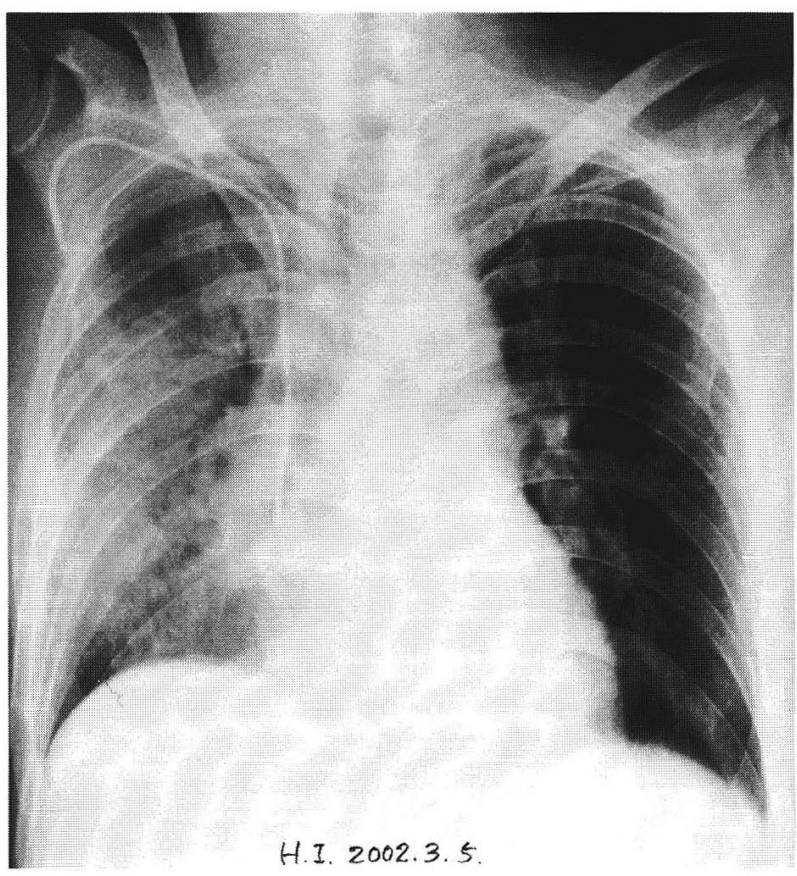

Fig. 8. Chest X-ray finding of Case 2 on the day before his death showed pneumonia in the right lung.

に死亡した. 剖検は行えなかつた.

この症例から検出・同定された Cunninghamella elegans を Sabouraud glucose 培地で培養した形態は Fig. 9 の通 りで，コロニーの先端は毛の様に延びていた.

なお NCCLS の方法 ${ }^{2)} に$ 従って測定したC. elegansに 対する AMPH の最小発育阻止濃度 (MIC) は $1 \mu \mathrm{g} / \mathrm{m} l$ であった。

\section{本邦報告例}

以下本邦で接合菌症として報告された症例を集計し検 討した結果を報告する.

1907 年（明治 40 年）の官報に掲載された稲田龍吉の 学位論文の審査結果に関する記事中に揭載された症例が 木邦第 1 例である. 従来は 1908 年の医学中央雑誌に記 載された稲田の報告が最初とされていた。しかし国立国 会図書館で遡って調べると, 1908 年の文献は 1907 年の ものと全く同じ内容であった.

1907 年の稲田の発表以降 1950 年（昭和 25 年）までは 入手出来る資料がなく集計出来なかつた. 今回報告した 2 症例に 2002 年 3 月末までの本邦報告例を出来るだけ 重複を避けて集計 ${ }^{3-161)}$ すると204例に上った（Table 1 〜 4). 個々に発表し, その後数年間にわたる症例をまと めた報告や, 担当臨床科と病理学教至が別々に発表した 症例などがあるため, 年代ごとの発表例数の集計は行わ なかったが, 最近は報告例数も増加傾向にある.

年齢性別が不詳の 2 名および年齢不詳の 1 名の計 3 名 を除いた 201 名につき年齢・性・病型別に集計すると Table 5 に示す通りである. 全体では男性：123名，女性 78 名で男性が女性の 1.6 倍, 51 60 歳代が最も多く, 平 均年齢は男性 (44.9歳) ·女性（46.4 歳）で男性が若干 
Table 1. Reported cases of zygomycosis in Japan

\begin{tabular}{|c|c|c|c|c|c|c|}
\hline \multicolumn{2}{|c|}{ Year } & \multirow{2}{*}{$\frac{\text { Sex }}{M}$} & \multirow{2}{*}{$\begin{array}{c}\text { Underlying disease } \\
\text { Solid cancer and typhoid }\end{array}$} & \multirow{2}{*}{$\begin{array}{l}\text { Diagnostic method } \\
\text { Autopsy }\end{array}$} & \multicolumn{2}{|l|}{ Reference } \\
\hline 1 & ? & & & & Inada $\mathrm{R}^{3)}$ & 1908 \\
\hline 2 & 30 & $\mathrm{~F}$ & Pulmonary tuberculosis & $?$ & Takahashi $\mathrm{Y}^{4)}$ & 1950 \\
\hline 3 & 42 & $\mathrm{~F}$ & Agranulocytosis & Autopsy & Nasu T et al. ${ }^{5)}$ & 1955 \\
\hline 4 & 59 & $\mathrm{M}$ & Lymphosarcoma & Autopsy & Ohmori R et al. ${ }^{6)}$ & 1955 \\
\hline 5 & 56 & M & Non-Hodgkin's lymphoma? & Autopsy & Nasu T et al..$^{7)}$ & 1956 \\
\hline 6 & 39 & $\mathrm{M}$ & Subacute yellow liver atrophy & Autopsy & Matsumoto $\mathrm{M}$ et al. ${ }^{8)}$ & 1958 \\
\hline 7 & 56 & $\mathrm{~F}$ & Weil disease? & Autopsy & Nakao $\mathrm{K}$ et al. ${ }^{9)}$ & 1960 \\
\hline 8 & 23 & M & Aplastic anemia & Autopsy & & \\
\hline 9 & 69 & M & Lung cancer & Autopsy & & \\
\hline 10 & 57 & $\mathrm{M}$ & Acute pancreas necrosis & Autopsy & Sugimoto A et al. ${ }^{10\rangle}$ & 1960 \\
\hline 11 & 20 & $\mathrm{~F}$ & Acute myeloid leukemia & Autopsy & Miyake $\mathrm{M}$ et al. ${ }^{11)}$ & 1961 \\
\hline 12 & 20 & $\mathrm{~F}$ & Acute myeloid leukemia & Autopsy & & \\
\hline 131 & $/ 12$ & $\mathrm{~F}$ & Primary brain mucormycosis & Autopsy & & \\
\hline 14 & 39 & $\mathrm{M}$ & Acute yellow liver atrophy & Autopsy & Aisawa $\mathrm{S}$ et al. ${ }^{12)}$ & 1961 \\
\hline 15 & 19 & $\mathrm{M}$ & Aplastic anemia & Autopsy* & & \\
\hline 16 & 71 & $\mathrm{~F}$ & Krebsiela pneumonia & Autopsy & & \\
\hline 17 & 64 & M & Obstructive jaundice & Autopsy & & \\
\hline 18 & 16 & $\mathrm{~F}$ & Acute myeloid leukemia & Autopsy & Satake $\mathrm{S}$ et al. ${ }^{13)}$ & 1961 \\
\hline 19 & 14 & M & None & Autopsy & Matsumoto $\mathrm{N}$ et al. ${ }^{14)}$ & 1962 \\
\hline 20 & 42 & $\mathrm{M}$ & Acute myeloid leukemia & Autopsy & Segawa $\mathrm{S}$ et al. ${ }^{15)}$ & 1962 \\
\hline 21 & 17 & $\mathrm{M}$ & Subacute myeloid leukemia & Autopsy & Nishihara Y et al. ${ }^{16)}$ & 1963 \\
\hline 22 & 38 & $\mathrm{~F}$ & Liver cirrhosis & Autopsy & Suga J et al. ${ }^{17)}$ & 1963 \\
\hline 23 & 84 & $\mathrm{M}$ & Respiratory infection & Autopsy & Ueda $\mathrm{Y}$ et al. ${ }^{18)}$ & 1963 \\
\hline 24 & 21 & M & Cushing syndrome & Autopsy & Mashiba Y et al. ${ }^{19)}$ & 1963 \\
\hline 25 & 19 & $\mathrm{~F}$ & Acute myeloid leukemia & Autopsy & Ikemoto $\mathrm{H}$ et al. ${ }^{20\rangle}$ & 1964 \\
\hline 26 & 28 & $\mathrm{~F}$ & Unknown & Autopsy & Hukushiro Y et al. ${ }^{21)}$ & 1965 \\
\hline 27 & $?$ & $?$ & Acute myeloid leukemia & Autopsy & Watanabe $\mathrm{H}$ et al. ${ }^{22)}$ & 1965 \\
\hline 28 & 36 & M & Acute lymphatic leukemia & Autopsy & Hagihara $\mathrm{T}$ et $a l .{ }^{23)}$ & 1966 \\
\hline 29 & 61 & M & Pulmonary tuberculosis & Autopsy & Hagihara $\mathrm{T}$ et al. ${ }^{24)}$ & 1966 \\
\hline 303 & $/ 12$ & $\mathrm{~F}$ & Rat-bite fever & Autopsy & Koide $\mathrm{G}$ et al. ${ }^{5)}$ & 1966 \\
\hline 31 & 17 & $\mathrm{~F}$ & Subacute myeloid leukemia & Autopsy & Tsuda $\mathrm{H}$ et al. ${ }^{26)}$ & 1966 \\
\hline 32 & 28 & $\mathrm{~F}$ & None & Autopsy & Ohta $\mathrm{G}$ et al. ${ }^{27)}$ & 1966 \\
\hline 33 & 52 & M & Acute renal failure & Autopsy & Yamamoto $\mathrm{S}^{28)}$ & 1966 \\
\hline 34 & $?$ & $?$ & Acute leukemia & Autopsy & Kinugasa $\mathrm{K}$ et al. ${ }^{29)}$ & 1967 \\
\hline 35 & 54 & $\mathrm{~F}$ & Glaucoma & Resected material & Shoji K et al. ${ }^{30)}$ & 1968 \\
\hline 367 & $/ 12$ & $\mathrm{~F}$ & Acute dyspeptic toxicosis & Autopsy & Ikeda I et $a l .{ }^{31)}$ & 1968 \\
\hline 37 & 54 & $\mathrm{~F}$ & None & Resected material & Sakata Y et al. ${ }^{32)}$ & 1968 \\
\hline 38 & 50 & M & Maxillary sinusitis & Resected material & Ishikura $\mathrm{T}$ et al. ${ }^{33)}$ & 1969 \\
\hline 39 & 29 & $\mathrm{~F}$ & Maxillary sinusitis & Resected material & & \\
\hline 40 & 53 & $\mathrm{~F}$ & Maxillary sinusitis & Resected material & Iwamoto $\mathrm{H}$ et al. ${ }^{34)}$ & 1969 \\
\hline 41 & 54 & $\mathrm{~F}$ & None & Resected material & Sekitani $\mathrm{T}$ et al. ${ }^{35)}$ & 1969 \\
\hline 42 & 73 & $\mathrm{~F}$ & None & Autopsy & Sasaki $\mathrm{H}$ et al. ${ }^{36)}$ & 1970 \\
\hline 43 & 46 & M & Acute myeloid leukemia & Autopsy & Yajima $\mathrm{K}$ et $a l .{ }^{37)}$ & 1971 \\
\hline 44 & 75 & $\mathrm{~F}$ & Acute myeloid leukemia & Autopsy & & \\
\hline 45 & 60 & $\mathrm{~F}$ & Serum hepatitis & Autopsy & Otsuki Y et al. ${ }^{38)}$ & 1972 \\
\hline 46 & 31 & $\mathrm{~F}$ & Acute myeloid leukemia & Autopsy & Sekine I et al. ${ }^{39)}$ & 1972 \\
\hline 47 & 14 & M & Acute myeloid leukemia & Autopsy & & \\
\hline 48 & 26 & M & Acute myeloid leukemia & Autopsy & & \\
\hline 49 & 55 & M & Gastic cancer & Autopsy & & \\
\hline 50 & 43 & M & Lung cancer & Autopsy & Jo $\mathrm{K}$ et al. ${ }^{40)}$ & 1972 \\
\hline 51 & 33 & M & Acute myeloid leukemia & Autopsy & Ito I et al. ${ }^{41)}$ & 1973 \\
\hline 52 & 51 & M & Diabetes mellitus & Autopsy & Shibata A et al. ${ }^{42)}$ & 1974 \\
\hline 53 & 5 & M & Mucor asthma & Skin test & Teramiti Y et al. ${ }^{43)}$ & 1974 \\
\hline 54 & 9 & $\mathrm{~F}$ & Mucor asthma & Skin test & & \\
\hline
\end{tabular}

$*:$ case diagnosed before death and confirmed by autopsy

MDS: Myelodysplastic syndrome, SLE: Systemic lupus erythematosis, 
Table 2. Reported cases of zygomycosis in Japan (continued-1)

\begin{tabular}{|c|c|c|c|c|c|c|}
\hline \multicolumn{2}{|c|}{ Year } & Sex & Underlying disease & Diagnostic method & Reference & \\
\hline 55 & 5 & $\mathrm{M}$ & Mucor asthma & Skin test & & \\
\hline 56 & 3 & M & Mucor asthma & Skin test & & \\
\hline 57 & 39 & M & Acute myeloid leukemia & Autopsy & Suzuki T et al. ${ }^{44)}$ & 1975 \\
\hline 58 & 61 & $\mathrm{~F}$ & Aplastic anemia & Autopsy & Suzuki S et al. ${ }^{45)}$ & 1975 \\
\hline 59 & 30 & M & Diabetes mellitus & Resected material & Inuyama $\mathrm{M}$ et $a l .{ }^{46)}$ & 1975 \\
\hline 60 & 64 & $\mathrm{~F}$ & Progressive gangrenous rhinitis & Autopsy & Inuyama $\mathrm{M}$ et $a l .{ }^{47)}$ & 1976 \\
\hline 61 & 55 & $\mathrm{~F}$ & Acute myeloid leukemia & Autopsy* & Wada J et al. ${ }^{48)}$ & 1976 \\
\hline 62 & 11 & $\mathrm{M}$ & Aplastic anemia & Autopsy & Uchiyama $\mathrm{F}$ et al. $^{49)}$ & 1977 \\
\hline 63 & 39 & $\mathrm{~F}$ & None & Autopsy & Owada $\mathrm{S}$ et al. ${ }^{50)}$ & 1977 \\
\hline 64 & 60 & $\mathrm{~F}$ & Aplastic anemia & Autopsy & Tanaka $\mathrm{M}$ et al. ${ }^{51)}$ & 1977 \\
\hline 65 & 45 & $\mathrm{M}$ & Acute myeloid leukemia & Autopsy & Kumakura $\mathrm{M}$ et al. ${ }^{52)}$ & 1977 \\
\hline 66 & 29 & $\mathrm{M}$ & Acute leukemia & Autopsy & Kawashima $\mathbf{K}$ et al. ${ }^{53)}$ & 1977 \\
\hline 67 & 34 & $\mathrm{M}$ & Acute leukemia & Autopsy & & \\
\hline 68 & 55 & M & Acute myeloid leukemia & Autopsy & Kojiro M et al. ${ }^{54)}$ & 1978 \\
\hline 69 & 61 & M & Lung cancer & Autopsy & Watanabe $\mathrm{K}^{55)}$ & 1978 \\
\hline 70 & 54 & $\mathrm{M}$ & Hyperthyroidism & Autopsy* & Ito $\mathrm{A}^{56)}$ & 1978 \\
\hline 71 & 52 & $\mathrm{M}$ & None & Resected material & Matsushima $\mathrm{T}$ et al. ${ }^{57)}$ & 1980 \\
\hline 72 & 52 & $\mathrm{M}$ & Diabetes mellitus & Resected material & & \\
\hline 73 & 67 & M & Old tuberculosis and pleuritis & Alive (fungus ball) & & \\
\hline 74 & 39 & $\mathbf{M}$ & Acute myeloid leukemia & Autopsy & & \\
\hline 75 & 63 & $\mathrm{M}$ & Acute monocytic leukemia & Autopsy & & \\
\hline 76 & 33 & $\mathrm{~F}$ & Acute monocytic leukemia & Autopsy & Tanke G et $a l .{ }^{58)}$ & 1980 \\
\hline 77 & 56 & $\mathrm{~F}$ & Primary pulmonary mucormycosis & Resected material & Shimabukuro $\mathrm{K}$ et al. ${ }^{59)}$ & 1980 \\
\hline 78 & 28 & $\mathrm{M}$ & Aplastic anemia & Autopsy & Akiyama $\mathrm{K}$ et al. ${ }^{60)}$ & 1980 \\
\hline 79 & 7 & $\mathrm{M}$ & Aplastic anemia & Autopsy & Ito $\mathrm{M}$ et al. ${ }^{61)}$ & 1980 \\
\hline 80 & 7 & $\mathrm{~F}$ & Acute myeloid leukemia & Resected material & Miyamoto $\mathrm{R}$ et al. ${ }^{62)}$ & 1981 \\
\hline 81 & 63 & $\mathrm{~F}$ & Acute myeloid leukemia & Autopsy & Takase $\mathrm{S}$ et al. ${ }^{63)}$ & 1981 \\
\hline 82 & 37 & $\mathbf{M}$ & Acute myeloid leukemia & Autopsy & Natori $\mathrm{H}$ et al. ${ }^{64)}$ & 1982 \\
\hline 83 & 49 & $\mathrm{~F}$ & None & $?$ & Ichimura $\mathrm{K}$ et al. ${ }^{65)}$ & 1982 \\
\hline 84 & 46 & $\mathrm{~F}$ & None & $?$ & & \\
\hline 85 & 45 & $\mathrm{~F}$ & None & Biopsy (Dead) & & \\
\hline 86 & 37 & $\mathbf{F}$ & None & $?$ & & \\
\hline 87 & 77 & $\mathrm{~F}$ & None & Biopsy (Alive) & & \\
\hline 88 & 45 & $\mathbf{F}$ & None & Resected material & Yao K et al. ${ }^{66)}$ & 1982 \\
\hline 89 & 49 & M & Diabetes mellitus & Resected material & Suzuki A et al. ${ }^{67)}$ & 1982 \\
\hline 90 & 51 & $\mathbf{M}$ & Diabetes mellitus & Resected material & Horikoshi Y et al. ${ }^{68)}$ & 1984 \\
\hline 91 & 46 & $\mathrm{M}$ & Non-Hodgkin's lymphoma & Autopsy & Sugiyama $\mathrm{Y}$ et al. ${ }^{69)}$ & 1984 \\
\hline 92 & 41 & M & Chronic myeloid leukemia & Autopsy & & \\
\hline 93 & 59 & $\mathrm{M}$ & Acute myeloid leukemia & Autopsy & & \\
\hline 94 & 44 & $\mathrm{M}$ & Acute lymphatic leukemia & Autopsy & Hosokawa $\mathrm{T}$ et al. ${ }^{70)}$ & 1984 \\
\hline 95 & 24 & $\mathbf{M}$ & Acute myeloid leukemia & Autopsy & Honda $\mathrm{N}$ et al. ${ }^{71)}$ & 1984 \\
\hline 96 & 26 & $\mathbf{M}$ & Non-Hodgkin's lymphoma & Autopsy & & \\
\hline 97 & 35 & $\mathbf{M}$ & Acute myeloid leukemia & Autopsy & & \\
\hline 98 & 69 & $\mathbf{M}$ & Acute myeloid leukemia & Autopsy & & \\
\hline 99 & 13 & $\mathrm{M}$ & Acute myeloid leukemia (M2) & Autopsy & Fujisawa $\mathrm{K}$ et al. ${ }^{72)}$ & 1985 \\
\hline 100 & 32 & M & Acute myelomonocytic leukemia & Resected material & Taneichi $\mathrm{K}$ et al. ${ }^{3)}$ & 1985 \\
\hline 101 & 24 & $\mathrm{M}$ & Brain mucormycosis & Resected material & Shinizu K et al. ${ }^{74)}$ & 1985 \\
\hline 102 & 68 & $\mathrm{~F}$ & Ethomoidal mucormycosis & Resected material & Sugiyama Y et al. ${ }^{75)}$ & 1985 \\
\hline 103 & 37 & $\mathrm{M}$ & Paranasal mucormucosis & Resected material & Hentona $\mathrm{H}$ et $a l_{.}{ }^{76)}$ & 1985 \\
\hline 104 & 8 & $\mathrm{M}$ & Acute lymophatic leukemia & Open lung biopsy & Ohtake $\mathrm{M}$ et $a l^{77)}$ & 1986 \\
\hline 105 & 29 & M & Aplastic anemia & Autopsy & Uchiyama A et al. ${ }^{78)}$ & 1987 \\
\hline 106 & 52 & $\mathrm{~F}$ & Aplastic anemia & Autopsy & & \\
\hline 107 & 64 & $\mathrm{~F}$ & Chronic renal failure & Autopsy & Arimura Y et al. ${ }^{79)}$ & 1988 \\
\hline 108 & 10 & $\mathbf{M}$ & Acute myeloid leukemia & Autopsy* & Dantani $\mathrm{N}$ et al. ${ }^{80)}$ & 1988 \\
\hline 109 & 15 & $\mathrm{~F}$ & Acute myeloid leukemia & Autopsy* & & \\
\hline 110 & 51 & $\mathrm{M}$ & Aplastic anemia & Autopsy & Hosokawa $\mathrm{T}$ et al. ${ }^{81)}$ & 1988 \\
\hline
\end{tabular}


Table 3. Reported cases of zygomycosis in Japan (continued-2)

\begin{tabular}{|c|c|c|c|c|c|c|}
\hline \multicolumn{2}{|c|}{ Year } & \multirow{2}{*}{$\frac{\text { Sex }}{M}$} & \multirow{2}{*}{$\begin{array}{r}\text { Underlying disease } \\
\text { Chronic renal failure }\end{array}$} & \multirow{2}{*}{$\begin{array}{l}\text { Diagnostic method } \\
\text { Autopsy }\end{array}$} & \multicolumn{2}{|l|}{ Reference } \\
\hline 111 & 38 & & & & Hisanaga $\mathrm{S}$ et al. ${ }^{82)}$ & 1988 \\
\hline 112 & 51 & $\mathrm{M}$ & Acute lymophatic leukemia & Resected material & Kondoh Y et al. ${ }^{83)}$ & 1989 \\
\hline 113 & 50 & $\mathrm{M}$ & Chronic renal failure & Autopsy & Arizono $\mathrm{K}$ et $a l^{84)}$ & 1989 \\
\hline 114 & 24 & $\mathrm{~F}$ & Chronic renal failure & Autopsy & Tsuruta $\mathrm{Y}$ et $a l .{ }^{85)}$ & 1989 \\
\hline 115 & 36 & $\mathrm{~F}$ & Acute myeloid leukemia & Resected material & Nagae $\mathrm{D}$ et al. ${ }^{86)}$ & 1989 \\
\hline 116 & 43 & $\mathrm{~F}$ & Diabetes mellitus & Autopsy & Ishida $\mathrm{M}$ et al. ${ }^{87)}$ & 1989 \\
\hline 117 & 71 & $\mathrm{M}$ & Diabetes mellitus & Resected material & & \\
\hline 118 & 55 & $\mathrm{M}$ & None & Resected material & & \\
\hline 119 & 69 & $\mathrm{~F}$ & None & Resected material & & \\
\hline 120 & 68 & F & None & Resected material & & \\
\hline 121 & 42 & $\mathrm{M}$ & Acute renal failure & Autopsy & Kimura $\mathrm{M}$ et al. ${ }^{88)}$ & 1990 \\
\hline 122 & 60 & $\mathrm{M}$ & None & Autopsy & Hayashi A et al. ${ }^{89)}$ & 1990 \\
\hline 123 & 74 & $\mathrm{~F}$ & Chronic myeloid leukemia & Autopsy & Tsuji $\mathrm{K}$ et al. ${ }^{90)}$ & 1990 \\
\hline 124 & 40 & $\mathrm{~F}$ & None & Resected material & Yamamoto $\mathrm{H}$ et al. ${ }^{91)}$ & 1990 \\
\hline 125 & 34 & $\mathrm{M}$ & Acute myeloid leukemia & Abscess & Chiba $\mathrm{N}$ et al. ${ }^{92)}$ & 1990 \\
\hline 126 & 34 & $\mathrm{M}$ & Acute myeloid leukemia & Autopsy & Iwatsu T et al. ${ }^{93)}$ & 1990 \\
\hline 127 & 38 & $\mathrm{~F}$ & Chronic renal failure & Autopsy & Yagihashi $\mathrm{S}$ et al. ${ }^{94)}$ & 1991 \\
\hline 128 & 51 & $\mathrm{M}$ & Hodgkin's disease & Autopsy & Kusunoki T et al. ${ }^{95)}$ & 1991 \\
\hline 129 & 61 & $\mathrm{M}$ & None & Open lung biopsy & Kutsuzawa T et al..$^{96)}$ & 1991 \\
\hline 130 & 57 & $\mathrm{M}$ & None & Resected material & Sugama $\mathrm{S}$ et $a l^{97)}$ & 1991 \\
\hline 131 & 57 & $\mathrm{~F}$ & Acute renal failure & Resected material & Kaneko $\mathrm{T}$ et al. ${ }^{98)}$ & 1991 \\
\hline 132 & 62 & $\mathrm{~F}$ & Acute myelomonocytic leukemia & Pleural effusion & Hukuda $\mathrm{N}$ et al. ${ }^{99)}$ & 1992 \\
\hline 133 & 55 & $\mathrm{M}$ & Perforative peritonitis & Paranasal biopsy & Ohde $\mathrm{H}$ et al. ${ }^{100)}$ & 1992 \\
\hline 134 & 57 & $\mathrm{~F}$ & Acute promyelocytic leukemia & Autopsy & Harada $\mathrm{M}$ et al. ${ }^{101)}$ & 1992 \\
\hline 135 & 63 & $\mathrm{~F}$ & $\operatorname{MDS}(\mathrm{RA})$ & Autopsy & Misawa $\mathrm{M}$ et al. ${ }^{102)}$ & 1992 \\
\hline 136 & 42 & $\mathrm{M}$ & Acute lymophatic leukemia & Autopsy & & \\
\hline 137 & 48 & $\mathrm{M}$ & Renal failure (renal transplantation) & Nasal biopsy & Iizuka $\mathrm{T}$ et al. ${ }^{103)}$ & 1992 \\
\hline 138 & 50 & $\mathrm{M}$ & None & Resected material & Shiozawa $\mathrm{N}$, et al. ${ }^{104)}$ & 1992 \\
\hline 139 & 78 & M & Acute myeloid leukemia & Clinical diagnosis & Mimura M et al. ${ }^{105)}$ & 1992 \\
\hline 140 & 51 & $\mathrm{M}$ & Acute lymophatic leukemia & Resected material & Kato $\mathrm{H}$ et al. ${ }^{106)}$ & 1993 \\
\hline 141 & 80 & $\mathrm{~F}$ & MDS $\rightarrow$ Acute myeloid leukemia & Autopsy & Sasaki A et al. ${ }^{107)}$ & 1993 \\
\hline 142 & 56 & $\mathrm{M}$ & Diabetes mellitus & TBLB & Matsumura Y et al. ${ }^{108)}$ & 1993 \\
\hline 143 & 42 & $\mathrm{M}$ & Diabetes mellitus & Resected material & Hayashi $\mathrm{H}$ et al. ${ }^{109)}$ & 1993 \\
\hline 144 & 37 & M & Diabetes mellitus & Nasal biopsy & Yamanaka $\mathrm{T}$ et al. ${ }^{110)}$ & 1993 \\
\hline 145 & 74 & M & Visual disturbance & Paranasal biopsy & Ochiai $\mathrm{H}$ et al. ${ }^{111)}$ & 1993 \\
\hline 146 & 65 & $\mathrm{M}$ & Diabetes mellitus & Paranasal biopsy & Takahashi Y et al. ${ }^{112)}$ & 1993 \\
\hline 147 & 49 & M & Acute myeloid leukemia & Autopsy & Hukushiro $\mathrm{R}$ et al. ${ }^{113)}$ & 1994 \\
\hline 148 & 63 & $\mathrm{~F}$ & Diabetes mellitus & Autopsy & Tokuda T et al. ${ }^{114)}$ & 1995 \\
\hline 149 & 63 & $\mathrm{~F}$ & Acute promyelocytic leukemia & Autopsy & Torii I et al. ${ }^{115)}$ & 1995 \\
\hline 150 & 85 & M & Generalized seizure & Resected material & Maeda Y et al. ${ }^{116)}$ & 1995 \\
\hline 151 & 37 & $\mathrm{M}$ & Diabetes mellitus & Nasal biopsy & Sugano $\mathrm{H}$ et al. ${ }^{117)}$ & 1995 \\
\hline 152 & 58 & $\mathrm{M}$ & SLE, Non-Hodgkin's lymphoma & Autopsy & Nakayama $\mathrm{S}$ et al. ${ }^{118)}$ & 1995 \\
\hline 153 & 62 & M & Brain abscess & Resected material & Okumiya $\mathrm{K}$ et al. ${ }^{19)}$ & 1995 \\
\hline 154 & 68 & M & None & Resected material & Kodama A et al. ${ }^{120)}$ & 1995 \\
\hline 155 & 44 & $\mathrm{~F}$ & Diabetes mellitus & Resected material & Mori A et al. ${ }^{121)}$ & 1995 \\
\hline 156 & 28 & M & Chronic myeloid leukemia, BL & Autopsy & Hunada $\mathrm{H}$ et al. ${ }^{122)}$ & 1996 \\
\hline 157 & 40 & M & Acute myeloid leukemia & TBLB & & \\
\hline 158 & 77 & M & Acute myeloid leukemia & Autopsy* & & \\
\hline 159 & 29 & $\mathrm{~F}$ & Acute myeloid leukemia & TBLB & & \\
\hline 160 & 30 & $\mathrm{M}$ & Acute myeloid leukemia & Autopsy & & \\
\hline 161 & 72 & $\mathrm{~F}$ & Acute myeloid leukemia & Autopsy* & & \\
\hline 162 & 36 & $\mathrm{~F}$ & Acute myeloid leukemia & Autopsy* & & \\
\hline 163 & 17 & M & Aplastic anemia & Autopsy & Sasaki S et al. ${ }^{123)}$ & 1996 \\
\hline 164 & 44 & $\mathrm{~F}$ & Diabetes mellitus & Resected material & Sekiya $\mathrm{E}$ et al. ${ }^{124)}$ & 1996 \\
\hline 165 & 61 & $\mathrm{M}$ & Refractory anemia & Autopsy & Yamaguchi A et al. ${ }^{125)}$ & 1996 \\
\hline
\end{tabular}


Table 4. Reported cases of zygomycosis in Japan (continued-3)

\begin{tabular}{|c|c|c|c|c|c|c|}
\hline & ear & Sex & Underlying disease & Diagnostic method & Reference & \\
\hline 166 & 44 & $\mathrm{M}$ & Diabetes mellitus & Resected material & Tojima $\mathrm{H}$ et al. ${ }^{126)}$ & 1997 \\
\hline 167 & 36 & $\mathbf{F}$ & Acute myeloid leukemia & Autopsy & Muramori $\mathrm{F}$ et al. ${ }^{127)}$ & 1997 \\
\hline 168 & 57 & $\mathrm{M}$ & Diabetes mellitus & Autopsy & Ohnishi $\mathrm{K}$ et al. ${ }^{128)}$ & 1997 \\
\hline 169 & 64 & $\mathrm{~F}$ & None & Bronchial secretion & Genba $\mathrm{H}$ et al. ${ }^{129)}$ & 1997 \\
\hline 170 & 51 & $\mathrm{~F}$ & Renal failure & Necropsy & Shishihara T et al. ${ }^{130)}$ & 1997 \\
\hline 171 & 65 & $\mathrm{M}$ & Pulmonary fibrosis & BALF (dead) & Hashiguchi $\mathrm{K}$ et al. ${ }^{131)}$ & 1997 \\
\hline 172 & 63 & $\mathrm{M}$ & Acute myeloid leukemia (M2) & Autopsy* & Kitabayashi A et al. ${ }^{132)}$ & 1998 \\
\hline 173 & 62 & $\mathrm{M}$ & Orbital apex syndrome & Resected material & Umemura A et al. ${ }^{133)}$ & 1998 \\
\hline 174 & 53 & $\mathrm{M}$ & Diabetes mellitus & Autopsy & Hashimoto $\mathrm{T}$ et al. ${ }^{134)}$ & 1998 \\
\hline 175 & 29 & $\mathrm{M}$ & Aplastic anemia & Autopsy & Nishinari $\mathrm{T}$ et al. ${ }^{135)}$ & 1998 \\
\hline 176 & 12 & $\mathrm{M}$ & Acute lympocytic leukemia & Autopsy* & Hara $\mathrm{H}^{136)}$ & 1998 \\
\hline 177 & 45 & $\mathrm{M}$ & None & Resected material & Kawakami J et al. ${ }^{137)}$ & 1998 \\
\hline 178 & 50 & $\mathrm{M}$ & $\operatorname{MDS}(\mathrm{RA})$ & Autopsy & Senzaki $\mathrm{H}$ et al. ${ }^{138)}$ & 1999 \\
\hline 1791 & $1 / 12$ & $\mathrm{~F}$ & Junctional epidermolysis bullosa & Autopsy & Kawai $\mathrm{H}$ et al. ${ }^{139)}$ & 1999 \\
\hline 180 & 56 & $\mathrm{~F}$ & None & Resected material & Matsumoto I et al. ${ }^{140)}$ & 1999 \\
\hline 181 & 51 & $\mathrm{M}$ & Diabetes mellitus & Autopsy & Horikoshi $\mathrm{T}$ et al. ${ }^{141)}$ & 1999 \\
\hline 182 & 65 & $\mathbf{F}$ & Diabetes mellitus & Autopsy & Matsuura $\mathrm{H}$ et al. ${ }^{142)}$ & 1999 \\
\hline 183 & 41 & $\mathrm{M}$ & Acute myeloid leukemia & Autopsy* & Kawagoe $\mathrm{Y}$ et al. ${ }^{143)}$ & 1999 \\
\hline 184 & 61 & $\mathrm{M}$ & Diabetes mellitus & Autopsy & Makino $\mathrm{T}$ et al. ${ }^{144)}$ & 1999 \\
\hline 185 & 82 & $\mathrm{~F}$ & Renal failure & Autopsy & Ohno $\mathrm{M}$ et al. ${ }^{145)}$ & 1999 \\
\hline 186 & 64 & $\mathbf{M}$ & MDS & Autopsy & Mori T et al. ${ }^{146)}$ & 1999 \\
\hline 187 & 16 & $\mathrm{~F}$ & Acute myeloid leukemia & Autopsy* & Izumi $\mathrm{N}$ et al. ${ }^{147)}$ & 2000 \\
\hline 188 & 58 & $\mathrm{~F}$ & Aplastic anemia $\rightarrow$ MDS & Autopsy* & Miyata Y et al. ${ }^{148)}$ & 2000 \\
\hline 189 & 53 & M & None & Pulmonary biopsy & Huruichi S et al. ${ }^{149)}$ & 2000 \\
\hline 190 & 55 & M & Acute myeloid leukemia & Pulmonary biopsy & & \\
\hline 191 & 52 & M & Non-Hodgkin's lymphoma & Pulmonary biopsy & & \\
\hline 192 & 81 & M & Chronic myelomonocytic leukemia & Autopsy & Terada $\mathrm{H}$ et al. ${ }^{150)}$ & 2000 \\
\hline 193 & 87 & $\mathrm{~F}$ & Diabetes mellitus & Clinical diagnosis & Makita A et al. ${ }^{151)}$ & 2000 \\
\hline 194 & 63 & $\mathrm{M}$ & Old tuberculosis & Autopsy* & Kourakata $\mathrm{H}$ et al. ${ }^{152)}$ & 2000 \\
\hline 195 & 60 & $\mathrm{~F}$ & Chronic monocytic leukemia & Sputa and drainage & Ito $\mathrm{T}$ et al. ${ }^{153)}$ & 2001 \\
\hline 196 & 85 & $\mathrm{~F}$ & Chronic renal failure & Sputa & Maniwa $\mathrm{K}$ et al. ${ }^{154)}$ & 2001 \\
\hline 197 & 36 & M & None & Autopsy & Kimura $\mathrm{M}$ et al. ${ }^{155)}$ & 2001 \\
\hline 198 & 31 & M & Histiocytoma & Autopsy & Yamauchi $\mathrm{T}$ et al. ${ }^{156)}$ & 2002 \\
\hline 199 & 17 & M & MDS & Autopsy & Nishimura Y et al. ${ }^{157)}$ & 2002 \\
\hline 200 & 54 & M & Lung cancer & Resected material & Tomita $\mathrm{S}$ et al. ${ }^{158)}$ & 2002 \\
\hline 201 & 67 & $\mathrm{~F}$ & Uterine sarcoma & Autopsy & Ohashi $\mathrm{H}$ et al. ${ }^{159)}$ & 2002 \\
\hline 202 & 64 & M & Diabetes mellitus & Biopsy & Zaizen Y et al. ${ }^{160)}$ & 2002 \\
\hline 203 & 43 & M & NK-like T-cell lymphoma & Autopsy & This article & \\
\hline 204 & 52 & $\mathrm{M}$ & Acute lympocytic leukemia & Sputa & This article $^{161)}$ & 2002 \\
\hline
\end{tabular}

若かつた.

本症は鼻脳型, 肺病変や播種性病変を含む組織侵襲型 およびアレルギー型に大別される，鼻脳型は男性 29 名・ 女性 25 名と男女差は殆ど無く, 平均年齢では男性（51.1 歳）より女性 (48.2歳) が若干若かった. 播種型・肺型・ そのほかを含む組織侵襲型では男性 91 名，女性 51 名で 男女差が拡がっており, 平均年齢は男性 : 43 歳, 女性 : 45.6 歳と鼻脳型と異なって, 逆に男性が若かった.アレ ルギ一型（ムーコル喘息）は小児例 4 例・成人例 1 例, 男性 3 例・女性 2 例で, 皮内反応・誘発試験などで診断 されたもので，全て予後良好であった.

急性骨髄性白血病に合併して死亡した鼻脳・アレル ギー型以外で病型不明の 1 例を除いた 203 例を, 基礎疾 患別にまとめると Table 6 の通りである. 全体では白血
病 (66 例）が最も多く, 基礎疾患のない症例 (41 例), 糖 尿病 (23 例)，再生不良性貧血・腎不全（各 13 例）の順 であった．また deferrioxamine は腎不全 6 例（うち 1 例 は鼻脳型)，再生不良性貧血の 1 例の計 7 例に使用され ていた.

鼻脳型は基礎疾患のない症例（29例）や糖尿病患者 （16 例）に多く，55 例中 28 例（51\%）が軽快あるいは治 癒して退院していた.

播種型・肺型・心血管型などを含む組織侵襲型では白 血病その他の血液疾患が大半を占め (90例)，しかも急 性骨髄性白血病（45例），に最も多く合併していた，再生 不良性貧血 (13 例) ・ 腎不全 $(11$ 例 $)$ ・各種の呼吸器疾 患 $(9$ 例 $)$ ・糖尿病 $(7$ 例 $) \cdot$ 肝疾患 (6 例) の順に見ら れ，肺に限局した病変以外の症例では全例が死亡してい 
Table 5. Age, sex and type of zygomycosis in Japan (2 cases: age and sex unknown. 1 case: age unknown)

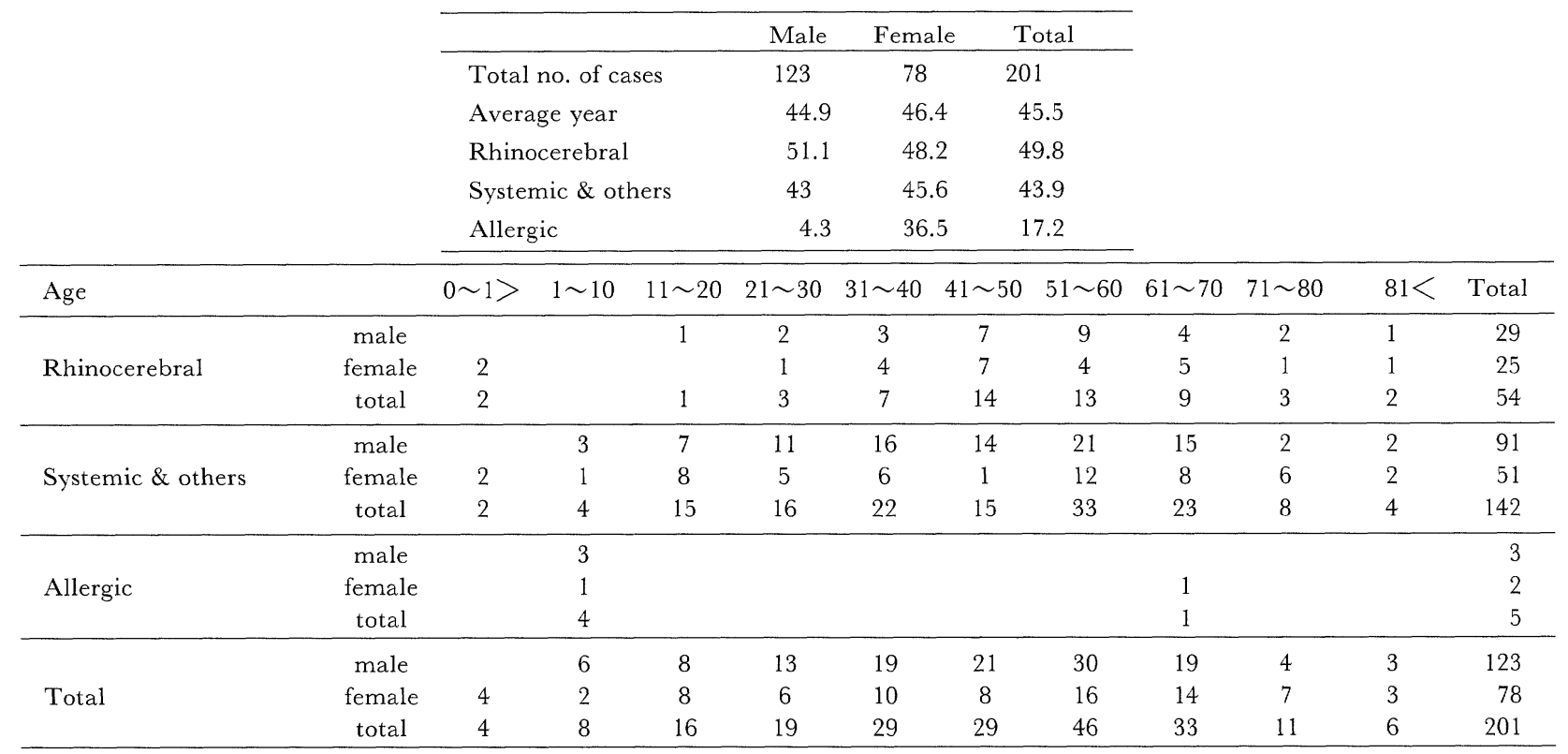

Table 6. Underlying diseases and type of zygomycosis

\begin{tabular}{|c|c|c|c|c|c|c|c|c|c|c|c|c|c|c|c|c|}
\hline \multirow[b]{2}{*}{ Underlying disease } & \multicolumn{3}{|c|}{ Rhinocerebral } & \multicolumn{2}{|c|}{ Disseminated } & \multicolumn{3}{|c|}{ Pulmonary } & \multicolumn{2}{|c|}{ Cardiovascular } & \multicolumn{2}{|c|}{ Gastrointestinal } & \multicolumn{2}{|c|}{1 Thyroid gl. } & \multirow[t]{2}{*}{ Allergy } & \multirow[b]{2}{*}{ Total } \\
\hline & $\begin{array}{l}\text { Total } \\
\text { cases }\end{array}$ & $\begin{array}{l}\text { Dead } \\
\text { cases }\end{array}$ & Unknown & $\begin{array}{l}\text { Total } \\
\text { cases }\end{array}$ & $\begin{array}{l}\text { Dead } \\
\text { cases }\end{array}$ & $\begin{array}{l}\text { Total } \\
\text { cases }\end{array}$ & $\begin{array}{l}\text { Dead } \\
\text { cases }\end{array}$ & Unknown & $\begin{array}{l}\text { Total } \\
\text { cases }\end{array}$ & $\begin{array}{l}\text { Dead } \\
\text { cases }\end{array}$ & $\begin{array}{l}\text { Total } \\
\text { cases }\end{array}$ & $\begin{array}{l}\text { Dead } \\
\text { cases }\end{array}$ & $\begin{array}{l}\text { Total } \\
\text { cases }\end{array}$ & $\begin{array}{l}\text { Dead } \\
\text { cases }\end{array}$ & & \\
\hline None & $29(20)$ & 10 & 3 & 1 & 1 & $6(6)$ & & & & & & & & & 5 & 41 \\
\hline Leukemia & $2(1)$ & 1 & & $24(1)$ & 24 & $33(16)$ & 26 & & 3 & 3 & 3 & 3 & 1 & 1 & & 66 \\
\hline Acute leukemia & & & & & & 2 & 2 & & & & 1 & 1 & & & & 3 \\
\hline Acute myeloid leukemia & $2(1)$ & 1 & & $20(1)$ & 20 & $19(10)$ & 17 & & 3 & 3 & 2 & 2 & 1 & 1 & & 47 \\
\hline Acute lymphocytic leukemia & & & & 1 & 1 & $7(4)$ & 4 & & & & & & & & & 8 \\
\hline Acute monocytic leukemia & & & & & & $4(2)$ & 2 & & & & & & & & & 4 \\
\hline Chronic myeloid leukemia & & & & 2 & 2 & 1 & 1 & & & & & & & & & 3 \\
\hline Chronic monocytic leukemia & & & & 1 & 1 & & & & & & & & & & & 1 \\
\hline Non-Hodgkin's lymphoma & & & & 4 & 4 & $2(1)$ & 1 & & & & & & & & & 6 \\
\hline Hodgkin's disease & 1 & 1 & & & & & & & & & & & & & & 1 \\
\hline Myelodysplastic syndrome & & & & $2(1)$ & 2 & 2 & 2 & & 1 & 1 & & & & & & 5 \\
\hline Multiple myeloma & & & & & & 1 & 1 & & & & & & & & & 1 \\
\hline Aplastic anemia & & & & $3(1)$ & 3 & 6 & 6 & & 3 & 3 & 1 & 1 & & & & 13 \\
\hline Agranulocytosis & & & & 1 & 1 & & & & & & & & & & & 1 \\
\hline Solid cancer & 1 & 1 & & 1 & 1 & $4(1)$ & 3 & & & & & & & & & 6 \\
\hline (Pulmonary cancer & 1 & 1 & & & & $2(1)$ & & & & & & & & & & 3) \\
\hline Chronic renal failure & $2(1)$ & 2 & & 5 & 5 & $4(2)$ & 3 & & 1 & 1 & $1(1)$ & 1 & & & & 13 \\
\hline Diabetes mellitus & $17(11)$ & 8 & & 1 & 1 & $5(5)$ & & & & & 1 & 1 & & & & 24 \\
\hline Pulmonary disease & & & & 1 & 1 & $6(3)$ & 3 & 1 & & & 2 & 2 & & & & 9 \\
\hline Gastrointestinal disease & $2(1)$ & 1 & & & & & & & & & & & & & & 2 \\
\hline Liver disease & & & & 1 & 1 & 1 & 1 & & 4 & 4 & & & & & & 6 \\
\hline Other disease & 1 & & & $4(1)$ & 4 & 2 & 2 & & 1 & 1 & 2 & 2 & & & & 10 \\
\hline Total & $55(35)$ & 24 & 3 & $48(4)$ & 48 & $72(34)$ & 48 & 1 & 13 & 13 & $10(1)$ & 10 & 1 & 1 & 5 & 204 \\
\hline
\end{tabular}

1 case with acute myeloid leukemia is unknown type of zycomycosis

( ): cases diagnosed before death or treated with antifungals

た. 切除標本や生検材料からの診断例や臨床的診断を例 含め 39例が生前に診断され, 23 名が軽快していた.

報告例のうち菌が分離・同定されたものは, 僅か 14 例 (6.9\%) にすぎなかつた (Table 7). その内訳は Rhizopus spp.・ Cunninghamell spp.がそれぞれ5例, Mucor spp.・Rhizomucor spp. が各 2 例であった.

生前診断方法・治療法に関しては Table 8 の通りであ
る. 鼻脳型では55例中, 生前診断された症例は, 手術・ 生検あるいは排膿術が施行された 32 例, 検査所見や臨 床症状より診断された 2 例の計 34 例で, 何らかの抗真 菌剤療法を行った症例は 15 例あり, うち 12 例は $\mathrm{AMPH}$ で，1例では fluconazole（FLCZ）による治療が行われ ていた. 剖検で初めて診断された症例が 17 例，3例は転 帰不明であった. 生前診断例のうち 7 例は死亡してい 
Table 7. Isolated species of Zygomycetes

\begin{tabular}{lrr}
\hline Mucor spp. & 2 & \\
Rhizopus spp. & 5 & \\
$\quad$ Rhizopus oryzae & & 2 \\
$\quad$ Rhizopus microsporus var. rhizopodifomis & & 2 \\
Rhizomucor spp. & 2 & \\
$\quad$ Rhizomucor pusillus & & 1 \\
$\quad$ Rhizomucor septatus & & 1 \\
Cunninghamella spp. & 5 & \\
$\quad$ Cunninghamella bertholletiae & & 4 \\
$\quad$ Cunninghamella elegans & & 1 \\
\hline
\end{tabular}

Table 8. Antemortem diagnostic methods and antifungal therapy of reported cases of zygomycosis in Japan

\begin{tabular}{|c|c|c|}
\hline & & Dead cases \\
\hline \multicolumn{3}{|l|}{ Rhinocerebral type (54 cases) } \\
\hline Antemortem diagnosis & 34 & 7 \\
\hline Operation or drainage & 32 & 5 \\
\hline Clinical diagnosis & 2 & 2 \\
\hline \multicolumn{3}{|l|}{ Operation or drainage with } \\
\hline amphotericin B therapy & 12 & 1 \\
\hline flucytosine therapy & 1 & \\
\hline unknown antifungal agent & 1 & 1 \\
\hline amphotericin B therapy only & 1 & 1 \\
\hline \multicolumn{3}{|c|}{ Disseminated, Pulmonary, and Other Tissue Invasive type (144 cases) } \\
\hline Antemortem diagnosis & 39 & 16 \\
\hline Operation & 15 & 2 \\
\hline Lung biopsy & 9 & 2 \\
\hline Sputum culture and drainage & 1 & \\
\hline Sputum culture & 2 & 2 \\
\hline Culture of pleural effusion & 1 & \\
\hline Clinical diagnosis & 11 & 10 \\
\hline \multicolumn{3}{|l|}{ Cases treated with antifungals ( 26 cases) } \\
\hline (operation only & 13 & 3) \\
\hline amphotericin B after operation & 3 & \\
\hline amphotericin B inhalation after operation & 1 & \\
\hline fluconazole after operation & 1 & \\
\hline \multicolumn{3}{|l|}{ itraconazole and inhalation of amphotericin B } \\
\hline after operation & 1 & 1 \\
\hline \multicolumn{3}{|l|}{ amphotericin B changed to itraconazole } \\
\hline after operation & 1 & \\
\hline $\begin{array}{l}\text { amphotericin B changed to itraconazole, } \\
\text { and then operated }\end{array}$ & 1 & \\
\hline \multicolumn{3}{|l|}{ operation after combination therapy } \\
\hline with amphotericin B and flucytosine & 1 & \\
\hline \multicolumn{3}{|l|}{ combination therapy with amphotericin B and } \\
\hline flucytosine after transbronchial biopsy & 1 & \\
\hline amphotericin B & 7 & 6 \\
\hline AmBisome & 1 & 1 \\
\hline \multicolumn{3}{|l|}{ combination therapy with } \\
\hline amphotericin B and flucytosine & 1 & 1 \\
\hline amphotericin B changed to fluconazole & 1 & 1 \\
\hline miconazole & 1 & \\
\hline fluconazole & 1 & 1 \\
\hline itraconazole changed to amphotericin B & 1 & 1 \\
\hline itraconazole and instillation of amphotericin B & 1 & 1 \\
\hline fluconazole added with amphotericin B later & 1 & 1 \\
\hline unknown therapy & 1 & 1 \\
\hline Allergic type: All 5 cases were diagnosed before death & & \\
\hline
\end{tabular}

た. 抗真菌剂で治療された症例のうち，1例は $\mathrm{AMPH}$ で治療中に，1例は使用薬剤が不明であるが治療中に死 亡し，最終的には 24 例が死亡しており，手術・生検また は排膿を行った症例の予後が良かった.

播種型・肺型のほか心血管系・胃腸管・甲状腺疾患を 含む症例は病変部位が特定されていない症例 1 例を除く と144例であった. 播種型は生前診断された 4 例を除く 44 例は全て剖検診断例であった. 一方肺型では72 例中 34 例が，消化管病変では 10 例中 1 例が生前に診断され ていた. 生前診断例は39例で，肺切除標本から診断され た症例 15 例のうち 2 例, 生検で診断された症例 9 例の うち 2 例が死亡していた. また喀痰培養で診断された症 例 2 例は全てが, 臨床診断例は 11 例中 10 例が死亡して いた. 胸水培養陽性 1 例および喀痰培養陽性で排膿を 行った 1 例は軽快していた. 外科的に処置された症例の 予後が良かつた.

いずれかの抗真菌剤で治療された症例は26例であっ た. 26 例中抗真菌剤投与前あるいは治療後に切除あるい は生検された症例が 7 例あり，1 例のみが死亡してい た. AMPHのみで治療された症例が 7 例で最も多かつ たが 6 例が死亡していた. そのほか miconazole を単独 で使用された症例は改善していた.

集計例のうち AMPH の使用量は 121 日間に5,000 mg を使用した症例以外は 1 日 20〜 40 mg 前後あるいはそれ 以下と投与量が少なく，しかも短期間の投与例が多かっ た.

ほかの感染症を合併していた症例は15例あり，アス ペルギルス症との合併 10 例, アスペルギルス症と消化 管粘膜カンジダ症の合併 1 例, 肺カンジダ症・Herpes simplex-2 型感染症・Cytomegalovirus 感染症がそれぞれ 1 例, そのほか食道カンジダ症合併 1 例で, 全て死亡して いた.

\section{考案}

接合菌症に関するシンポジウムは既に昭和 52 年 (1977 年）に「Phycomycosis (所謂ムーコル症)」として行わ れている ${ }^{162)}$. 当時は鼻脳型の報告が多かったのに比べ 最近は日和見感染症として発症した症例が増加してい る.

接合菌症を合併する基礎疾患としては，今回の集計に 見られたように白血病を含む血液悪性疾患・慢性貧血・ 糖尿病・腎不全・肝疾患・臓器移植などのほか, 本邦で は比較的少ないAIDSが挙げられる.しかし何ら基礎疾 患を有しない症例が $20 \%$ り, 鼻脳型に多く認められ た.

接合菌症の発症頻度は，Kontonyiannis DP らは，血液 悪性疾患剖検例の $1.9 \%{ }^{163)}$, 船田らは $2.1 \%$ と報告 ${ }^{122)}$ し ている.

1981 年から 2000 年までの 20 年間に我々の病院のおけ る総剖検数 4,071 例のうち接合菌症は僅か 2 例のみで, 血液疾患に合併した症例は 264 例中 1 例 $(0.4 \%)$ と極 めて少ないものであった. 
接合菌症発症の危険因子には, 好中球数が $500 / \mu l$ 以 下, リンパ球数が $1,000 / \mu l$ 以下, 症状出現 7 日以上前か ら血糖値が $200 \mathrm{mg} / \mathrm{d} l$ 以上が続いている場合, 症状出現 14 日以上前から $\mathrm{Cr}$ が $2.5 \mathrm{mg} / \mathrm{d} l$ 以上あるいは症状出現 4 週間以上前からステロイドが総量 $600 \mathrm{mg}$ 以上を投与さ れている場合などが挙げられている163).

その他腎不全例で deferrioxamine 使用例に多く合併 する事が注目されていた. 頻回の輸血に伴う血清鉄の増 加に対する鉄除去剤である deferrioxamine は鉄と同様 に接合菌の増殖を促進するとされ ${ }^{164)}$ ，腎不全例 13 例中 6 例 $(46.2 \%)$, 再生不良性貧血 13 例中 1 例 $(7.7 \%)$ に 合併していたが, 現在では輸血に代わり erythropoietin が投与されるようになり，このような症例は今後無くな るものと考えられる.

一方予後良好な因子としては, 肺病変を伴わない鼻脳 型，切除・郭清あるいは排膿を行った場合，好中球数の 回復が早く免疫機能の回復が早い場合などがある.

接合菌は外因性真菌であるため，経気道的に感染する。 そのため臨床的には呼吸器症状が最も多く見られ, 胸部 $\mathrm{X}$ 線上肺炎像・肺梗塞像・肺膿瘍様陰影を呈する。 その ほか集計例の中にはアスペルギローマと同様の菌球像を 呈した 1 例が認められた。

次いでクモ膜下出血, 副鼻腔炎あるいは膿瘍として見 られ，頭痛・めまい等を訴える。そ他胃腸管出血, 腹 膜炎, 肝炎などとして認められる. 画像診断では Aspergillus spp. による病変と極めて類似しており，しか も併存していることがあり 鑑別は困難なことが多い.

急激に発症して, 予後不良になることがある. 症例 1 では入院時より感染症を思わせる所見を認めないまま経 過していたが, 突然中枢神経症状を呈し, 胸部 X 線像に も異常陰影が出現し，急激に悪化し短期間に死亡したも ので末期感染と考えられる. そのため生前, 真菌症診断 のための検索が殆ど行えず，乙かも一般的に行われてい るFLCZ や ITCZ の予防投与を行っても本症を阻止でき ないのが実情であろう.

確定診断は病巣から得られた組織の病理検查および培 養による. しかし基礎疾患が重篤なことを考慮すると生 検は容易には行えない. 第 2 例のように肺病変が認めら れ，繰り返し真菌を検出した場合には接合菌症と診断可 能と考える. 従って菌検出のための努力が必要である.

病理学的には病巣内で $\mathrm{T}$ 字型に分岐し, Aspergillus spp. に比べやや幅が広く隔壁を有しない菌要素として見 られる.また Aspergillus spp. と同様に血管に親和性を有 し，血管を穿通する像が見られる.

Aspergillus spp. Pseudallescheria boydii Fusarium spp. 等 の糸状菌や Candida spp. による感染症と鑑別する必要が あるが，併存することがあり，鑑別は難しい165).

AMPH の全身投与のほか, 感染病巣の切除, 基礎疾患 の改善が重要であることは勿論である.治療には早期診 断が重要であり, 可能であれば診断のためも含めて外科 的に切除あるいは生検することが有用である. しかし早 期に診断されるのは 50\%以下であり, AMPH の全身投
与を行い切除しても, その予後は基礎疾患の状態に左右 される.

現在開発中のものを含めて, 接合菌に対して感受性を 有する抗真菌剤に AMPH, liposomal AMPH がある. ぞ ちらもAbsidia spinosaには抗菌力は若干弱いが，それ以 外のほぼ全ての接合菌に強以感受性を有する. そのほか ITCZ は Absidia spinosa, Mucor spp. に対して感受性は低 いが，ほかの接合菌には比較的良好な感受性を有してい るとされる ${ }^{166,167)}$. ITCZの経口剂では吸収が不十分な ことがあるため, 血中濃度を上げるには静注剤を用いる ベきであろう.

症例より検出された $C$. elegans に対する AMPH のMIC は $1 \mu \mathrm{g} / \mathrm{ml}$ で, AMPH $1 \mathrm{mg} / \mathrm{kg} /$ day を点滴静注した場 合，8時間程度で MICより低い值になることが予想さ れる ${ }^{168)}$. 有効血中濃度を長時間保つためには $1 \sim 1.5$ $\mathrm{mg} / \mathrm{kg} /$ 日あるいはそれ以上を, 数時間かけて点滴静注す る必要があると考えられる.

AMPH の総投与量に関しては $2,000 \mathrm{mg}$ 以上で反応が 見られるが, それ以下では予後不良とされる163).ただ基 礎疾患の状態によっては長期間の治療が必要になり, 期 待した効果が得られない事もあるが, 今回集計した症例 では, 恐らくは AMPH の副作用を恐れてのことと考え られるが, 使用量が極めて少なかった。

欧米では AmBisome も含めた AMPH のリピッド製剤 が数種市販されており,それぞれの効果について議論は ある.いずれも通常の AMPH に比べ腎障害などの副作 用が少なく, 投与量を増量できる利点がある. 効果に関 しては通常の AMPH との有意差はないとする報告 ${ }^{1699}$ のほか, リピッド製剂が良いとするものがある ${ }^{170)}$. 実際 には副作用が少なく増量して長期間投与出来, 効果を 期待できると思われる. 症例 2 では AmBisome 0.74〜 $1.47 \mathrm{mg} / \mathrm{kg} / \mathrm{day}$ を使用したが, 増量して $2.5 \sim 5 \mathrm{mg} / \mathrm{kg} /$ 日 あるいはそれ以上を用い, 早期に改善させる努力が必要 だったと考えられた.

そのほか白血球輸血や G-CSF の投与が有効とする報 告が見られる171, 172). 血液悪性疾患では化学療法による 白血球減少は必発であり, 発熱を伴うことが多い. 顆粒 球減少時, 生体の抵抗減弱部位に感染の「芽」が形成さ れ, 顆粒球が回復した時点で解熱するものの, 繰り返し 行わ的る化学療法時に病巣が拡大する傾向がある. その ため顆粒球減少期間を出来るだけ短縮し，「芽」の形成 を阻止するためにも, 白血球輸血や G-CSF などのサイ トカインは効果的と考えられる.

従来, 接合菌症は漠然と Mucor spp. によるものが最も 多いとされて来た. しかし今回の集計で分離・同定され た菌は僅か 14 例 $(6.8 \%)$ と少なく, Cunninghamella spp. や Rhizopus spp.によるものが比較的多かった. Weng $\mathrm{DE}$ らの報告でも 17 例中 6 例で分離・同定され, Absidia spp.・Rhizopus spp. が各 3 例で, 必ずしもMucor spp.が 多いわけではなかった。しかし 24 例中 16 例から菌が分 離され, Mucor spp.が最も多く, 次いでRhizopus spp, Cunninghmella spp. の順であったとする報告 ${ }^{163)} も$ あ. 
しかしこれらの真菌に対する MIC まで検索した報告は 自験例 1 例のみであつた.

接合菌症の実態を正確に把握するには, 切除例・剖検 例を含め菌の検出・同定に心掛けると同時に MIC の測 定を行い, 抗真菌剤の投与量を決定することなどが重要 と考えられる. また予後の改善には早期に強力な $\mathrm{AMPH}$ 療法を行うことが必要がある163).

\section{終わりに}

本症では血清学的補助診断法や PCR 法などによる検 索法が未だ確立されておらず，診断に苦慮すると共に， 基礎疾患が重篤なこと, AMPH 以外有効な治療薬凨が ない事もあって, 予後不良になることが多い. 強力な治 療を早期から行うためには早期診断が是非とも必要であ る. 生検以外確実な診断方法はないのが現状であるが, 喀痰・肺胞洗浄液の培養を含めた各種検体からの真菌検 索を積極的に繰り返し行う努力も必要と考える.

今後, 新たな血清学的診断法, 特にPCR 法を用いた DNA 診断法などの有効な補助診断法および確実に奏効 する薬剤の開発が望まれる.

謝 辞：AmBisome の輸入など快くご協力戴いた住友製 薬・中條英司氏，馬庭貴司氏に心より感謝申し上げます.

\section{文献}

1) Kwon-Chung KJ, Bennett JE: Mucormycosis (Phycomycosis, zygomycosis). In Medical Mycology (KwonChung KJ, Bennett JE ed), p.524-559, Lea \& Febiger, Philadelphia, 1992.

2) Nationl Committee for Clinical Laboratory Standards: Reference methods for broth dilution antifungal susceptibility testing of conidium-forming filamentous fungi. Proposed standard M-38-P. National Committee for Clinical Standards. Wayne, Pa. 1998.

3）稲田龍吉：プノエモノミコージス・ムコリナに就いて, 附ムコール・リツヨポヂフヨルミスに就いて．官報, 7143: 753-754，1907，(医中央誌 6: 471，1908.)

4) 高橋吉定：肺真菌症から分離した Rhizomucor septatusに ついて。臨床内児科 5: 411-413，1950.

5）那須 毅, 塩澤久要：汎発性真菌症の剖検例. 綜合臨 4 : 137-147, 1955.

6) Ohmori R, Maeda Y, Otaka Y:A case of so-called postoperative gastrointestinal hemorrhage and erosive esophagitis. Acta Path Jpn 5(suppl): 645-647, 1955.

7）那須 毅, 島村冨郎, 那須 聰：肺の Mucormycosis の 1 例。信州医誌 5: 354-358, 1956

8）松本道也, 石渡和男, 島峰徹郎：胃真菌症を伴える亜急 性黄色性肝萎縮症. 日消学会関東地方会, 1958, 10.

9) 中尾喜久, 前川 正, 見城武三郎, 服部理男, 大塚 敬, 須藤謙三郎, 高玉真光, 深井孝治 : Mucormycosis の 3 症 例. 最新医学 15: 1328-1337, 1960.

10）杉本顕俊, 山本重治, 本多光弥, 赤木正志, 安田青児 : 急 性膵壊死に合併したムーコル症の 1 剖検例. 綜合臨 $\mathbf{9}$ $145,1960$. 11）a). 三宅 仁, 奥平雅彦, 瀬戸輝一：ムーコル菌症 (Mucormycosis)。最新医学 16: 552-565, 1961.

11） b). 衣笠恵士, 中村晴臣, 斉藤昌信, 今村幸雄, 豊倉康夫, 高久史痋, 平嶋邦猛, 瀬戸輝一：急性白血病における真 菌感染. 内科 8: 944-950, 1961.

12）藍沢茂雄, 島峰徹郎, 上塚 昭, 広野さと: 消化管のム一 コル症，日臨 19: 2135-2144，1961.

13）佐竹清人, 関谷政雄, 大網 弘: 全身真菌症を合併し特 異な剖検所見を呈した急性骨髄性白血病の 1 例. 臨血 2: 241, 1961.

14) Matsumoto $N$, Sekitani $T$, Nakamura $T$, Awaya $H$ : A case report of meningeal mucormycosis with autopsy findings. Bull Yamaguchi Med School 9: 174-183, 1962.

15）瀬川宗助, 小黒昌夫, 塚田恒安, 速水一雄 : ム一コル菌 症を合併した緑色白血病の一例. 臨血 3: 275, 1962.

16）西原由朋, 富永秀敏, 津田頴彦, 中浦靖久：西急性骨髄 性白血病経過中に併発せるムーコル症の 1 剖検例. 日内 会誌 52: 551-552， 1963.

17）須賀純之助, 羽飼 昭, 加島 弘 : 眼症状を伴ったムー コル症の 1 剖検例。眼臨 17: 365-373， 1963.

18）上田 泰, 南 貞夫, 宇都宮光明, 石田尚志, 小山博誉 : Mucormycosis の一剖検例. 日内会誌 52: 44, 1963.

19）真柴雄二, 北村信一, 大貫寿征, 馬場正二, 小出 紀 : ムーコル菌症を併発したクッシング症候群の 1 例. 日内 分泌会誌 45: 272，1963.

20）池本秀雄, 中沢信八, 斎藤 脩：ムーコル菌症. 内科 9 : 913-920, 1964.

21）福代良一, 金原武司, 河村洋一：胃ムーコル菌症兼食道 カンジダ症. 真菌誌 6: 304, 1965.

22）渡辺洋望, 片海晟五, 大高裕一: 白血病に併発し, 穿孔 性虫垂炎を呈したムーコル症の 1 剖検例. 真菌誌 6: 304, 1965.

23）萩原忠文, 高橋淳司, 是永大公, 広原公昭, 堀内 篤, 勝 呂 長:アスペルギルスとムーコルの混合感染を認めた 急性白血病の 1 剖検例. 真菌誌 7: 209-213， 1966.

24）萩原忠文, 川村章夫, 岡安大仁, 勝呂 長, 岩田康人：異 種真菌の混合感染と思われる 2 剖検例. 真菌誌 7: 268 , 1966.

25）小出五郎, 植地正文, 石河利隆, 徐慶一郎：敗血症 (1. 小児ムーコル菌症).小児診療 29: 23-34，1966.

26）津田頴彦, 西原由朋, 富永秀敏, 織田卓五郎, 中浦靖久： 亜急性骨髄性白血病経過中に併発せるムーコル菌症の 1 例. 久留米医会誌 29: 635-641，1966.

27）大田五六, 大江国広, 河村洋一：基礎疾患不明の急性胃 ムーコル菌症の 1 剖検例. 治療, 48: 2141-2142, 1966.

28）山本俊輔：広汎性 Mucor 症の 1 剖検例. 医学のあゆみ 57: 528-529, 1966.

29）衣笠恵士，千葉省三：血液疾患における真菌症. 臨血 8: 342-352, 1967.

30）正司和夫, 井尻博三 : 眼症状を伴った脳型ムーコル症の 1 例. 眼紀 19: 1013-1015， 1968.

31）池田稲穂, 松山春郎：脳ムーコル症の 1 剖検例. 小児診 療 31 119-123, 1968.

32) Sakata Y, Higashi K, Kaneko K: Cerebral mucormycosis. 日外宝函 37: 895-901，1968.

33）石倉武雄, 河村正三, 岡田博允, 土屋 寛, 住田邦夫, 飯 村晃彦：真菌性上顎洞炎の臨床的並びに病理組織学的所 見. 日耳鼻 72: 857-867, 1969.

34）岩本彦之丞, 桂 万寿美, 藤巻龍枝 : 上顎癌と誤診され た真菌症の 2 例. 耳喉 4: 851-855，1969. 
35）関谷 透, 山田隆志, 原 八洲雄, 宮原正明: めまい症 例-Cerebral mucormycosis-. 耳喉 4: 147-157, 1969.

36）佐々木治夫, 福山和彦, 大島紀玖男, 乾 達, 山下隆造 : 上気道炎に続発したと考えられるムーコル症の 1 例. 耳 喉 42: 43-47, 1970.

37）矢島邦夫, 海塩毅一, 来生 哲, 伊藤政志, 若木邦彦: 急 性骨䯣性白血病に伴えるムーコル症. 日内会誌 60:444, 1971.

38）大朏祐治, 林 建彦: 沉発性ムーコル症と肺アスペルギ ルス症合併の 1 剖検例. 内科 30: 148-151, 1972.

39）関根一郎：ムーコル症の 4 剖検例報告. 熱帯医学 14: 176-185, 1972.

40）徐 勝常, 吉村 康, 奥野一裕, 中野正心, 原 耕平, 河 合紀生子, 隅田達男：肺癌に随伴した脳ムーコル症の一 剖検例. 臨床と研究 49: 3470-3475, 1972.

41）伊藤一郎, 高田昌純：Mucor による出血性肺梗塞を伴え る急性骨髄性白血病の臨床知見. 診療と新薬 10: 661666, 1973.

42）柴田温三, 高槻健介, 富田明夫, 柳田則之, 滝本 勲, 中 島伸夫 : 糖尿病ケトアシドーシスに合併したRhinocerebral mucormycosis の 1 剖検例. 内科 33: 180-183, 1974.

43）寺道由晃, 根本俊彦, 福村 豊: Mucor 過敏喘息. アレ ルギー 23: 271-277, 1974.

44）鈴木孝雄，田中鉄五郎，遠藤徳雄，松田 信，秋月 健, 木村秀夫, 吉田 博, 斎藤武郎, 浅野喜代子 : 肺動脈幹 におよぶムーコル血栓形成をみた急性骨髄性白血病の 1 剖検例. 臨血 16: 1141-1146, 1975.

45）鈴木成憲，荒木文雄：再生不良性貧血に合併した汎発性 Mucormycosis の 1 例. 医療 29: 177-181, 1975.

46）犬山征夫, 高崎 敬, 犬山幸子, 藤井一省, 岡田道雄 : 糖 尿病に合併した Rhinocerebral mucormycosis $の 1$ 例. 耳 喉 47: 345-350, 1975.

47）犬山征夫, 小津雷助, 朝岡一之, 中島康夫, 鳥潟親雄 : Rhinocerebral mucormycosis の一剖検例及び本疾患に関 する統計的観察. 耳鼻臨床 69: 907-917，1976.

48）和田順平, 岡安裕之, 鈴木洋司, 小川哲平, 長谷川弥人： 急性骨髄性白血病に合併したムーコル菌症による心筋梗 塞の 1 例. 臨血 17: 649, 1976.

49）内山富士雄, 小松田光真, 市川幸雄, 有森 茂 : ムーコ ル菌性心房内巨大血栓を伴った再生不良性貧血の 1 剖検 例. 臨血 18: 1378-1381，1977.

50）大和田滋, 山田 哲, 加藤康雄, 関野宏明, 中村紀夫 : 脳 幹および上部頝髄に発症したムーコル菌症の 1 例. 臨神 経 17: 231-236, 1977.

51）田中岑也, 広田 豊, 原一夫：肺ムーコル症を併発し た再生不良性貧血の 1 剖検例. 医療 31: 562-564， 1977.

52）熊倉 眞, 田村康二, 松岡松三, 黒川和泉, 山内春夫 : 急 性白血病に伴うムーコル菌症による急性心筋梗塞症の 1 剖検例. 内科 40: 866-870, 1977.

53）川島康平，上田竜三，竹山英夫，小林政英，森島泰雄，加 藤幸男, 鈴木久三, 若山喜久子, 山田一正 : 急性白血病 剖検症例における真菌症. 臨血 18: 1128-1136, 1977.

54）神代正道, 貴田秀樹, 松本 博, 金戸 昭, 中島文行, 下 川 泰：ムーコルによる肺動脈血栓形成, 出血性肺梗塞, 及び心内膜炎を合併した急性骨髄性白血病の 1 剖検例. 日臨 36: 3243-3247，1978。

55）渡辺一功：Phycomycosis（いわゆるムーコル症）内科 領域から一診断の問題点. 真菌誌 19: 101-107，1978.

56）伊藤 章：Phycomycosis (いわゆるムーコル症)・内科 領域から－治療の問題点. 真菌誌 19: 108-113，1978.
57) Matsushima $T$, Soejima R, Nakashima T.: Solitary pulmonary nodule caused by phycomycosis in a patient without obvious factors. Thorax 35: 877-878, 1980.

58）丹家元陽, 老籾宗忠, 馬場茂明, 白根博文, 鵜飼和浩 : ムーコル菌性肺動脈血栓症，アスペルギルス性肺炎，消 化管カンジダ症を合併した急性単球性白血病の 1 剖検 例. 総合臨 29: 2277-2281，1980.

59）島袋国定, 豊平謙, 伊東祐治, 篠原慎司：原発性肺 ムーコル症の 1 例. 臨放 25: 923-925，1980.

60）秋山一男, 木全心一, 千葉省三, 今村幸雄, 小坂樹徳 : Mucormycosis による著明な肺動脈血栓を認めた再生不 良性貧血の 1 剖検例. 日内会誌 64: 860-861， 1980.

61）伊藤正寛, 鳥越貞義, 広田久佳, 二宮剛美, 谷本康夫, 井 上正和, 筒井 孟, 神谷 斉, 桜井 実：再生不良性貧 血治療経過中に認められたムーコル菌による左心房内巨 大血栓症の 1 剖検例. 小肾診療 43: 304-308, 1980.

62）宮本礼子, 本郷輝明, 竹広 晃, 五十嵐良雄, 上山武郎, 原田幸雄, 森田豊彦：肺結核と肺ムーコル症を合併した 急性骨髄性白血病の 1 例. 臨血 22: 903-908, 1981.

63）高瀬真一, 佐々木豊志, 松尾英世, 中里洋一, 竹内秀夫, 土屋幸彦：Mucor による肺動脈血栓，肺梗塞，心内膜炎， 大動脈炎と肺アスペルギルス症を合併した急性骨䯣性白 血病の 1 剖検例. 内科 47: 714-717, 1981

64）名取英世, 江上康一郎, 田中 健, 安田佳織, 山口達夫, 加地正郎, 冨松久信, 神代正道 : ムーコル菌症による巨 大血栓, 脳血栓を合併した急性骨䯣性白血病の 1 剖検例. 臨血 23: 1496-1501， 1982.

65）市村恵一，星野知之，矢野 純，野末道彦，長井大二，木 村元俊, 江沢暁彦, 平出文久 : 鼻副鼻腔真菌症と眼合併 症. 耳喉 54: 57-63， 1982.

66）八尾和雄, 田代直樹, 高橋広臣, 斉藤 彰, 鈴木 徹, 古 川浩三：いわゆる上顎洞ムーコル症の 1 例. 耳展 25 : 661-668, 1982.

67）鈴木昭男, 高須昭彦, 八木沢幹夫, 八井田昌志, 西村忠 郎, 岩田重信, 林 尚孝: 副鼻腔ムーコル症の 1 例. 日 耳鼻 85: 64-65， 1982.

68）堀越裕一, 花島恒雄, 森田武子, 白石 透, 千葉保之, 石 井周一, 本内正雄, 宝田欣宏, 福田千文, 大塚俊通, 早川 欽哉, 久米 光 : 糖尿病患者にみられた肺ムーコル症の 1 例. 日胸疾会誌 22: 1147-1153，1984.

69）杉山幸比古, 和泉孝志, 佐々木憲二, 北村 諭, 高久史 麿, 山口和克：血液疾患に合併した有する有する肺病変 を沉発性ムーコル症の 3 剖検例. 日胸疾会誌 22: $214-$ 218, 1984.

70）細川隆文, 佐分利能生, 水谷良子, 糸賀 敬: 汎発性么一 コル症, アスペルギルス症を呈した急性リンパ性白血病 の 1 剖検例. 臨血 25: 1326-1331, 1984.

71）本田憲業, 住野清一, 大野真理子, 木野博至, 久田哲也, 毛利昌史：肺ムーコル症の 4 剖検例. 治療学 13: 548551, 1984.

72）藤沢康司, 望月 弘, 石戸谷尚子, 吉野則子, 広津卓夫, 赤塚順一：Mucor 性肺梗塞を呈した急性骨髉性白血病の 1 男児例. 小児臨床 38: 1741-1745, 1985.

73）種市幸二, 出野正孝, 今野孝彦, 芝木秀俊: 急性骨髄単球 性白血病の経過中にムーコル菌性肺梗塞を合併し, 肺葉 切除により治瘾した 1 例. 臨血 26: 96-100, 1985.

74）清水一志, 新谷俊幸, 伊藤丈雄, 中川俊男, 平井宏樹 : 脳 ムーコル症の 1 例. 道南医会誌 20: 128-131，1985.

75）杉山洋子, 大井益一, 板倉康夫：篩骨洞真菌症の 1 例. 耳喉 57: 211-214, 1985. 
76）辺土名 仁，竹生田勝次，石川紀彦，北野元生：上顎腫場 を思わせた副鼻腔真菌症. 耳喉 57: 405-410， 1985.

77）大竹正俊，小林真弓，相原令子，渡辺信雄，長井靖夫，村 松博行，松原 尚，原田吉憲：寛解導入時に肺ムーコル 症による再発性気胸を併発した ALLの 1 例. 日览誌 90: 1075-1080, 1986.

78）内山昭子，鈴木憲史，榎本英壽，田中一夫，武村民子： Mucorによる巨大肺動脈血栓を形成した再生不良性貧血 の 2 剖検例. 内科 60: 179-184，1987.

79）有村義宏，中林公正，北村 清，長沢俊彦，田中宇一郎， 中村 弥, 藤田親徳, 滝本雅文：鉄過㮃症を認める慢性 血液透析患者に生じたムーコル症の 1 例. 日内会誌 77 : 1884-1887，1988.

80）檀谷尚宏, 小林俊樹, 渋谷 温：肺ムーコル症を合併し た急性骨髄性白血病の 2 例. 小児内科 20: 1487-1492, 1988.

81）細川隆文, 山崎 力, 隈井 清, 野村邦雄, 岸川正純, 辻 浩一：肺動脈塞栓にて急死した重症再生不良性貧血の 1 剖検例. 大分県立病院誌 17: 123-126，1988,

82） 久永修一，藤元昭一，脇坂 治，山本良高，田仲謙次郎， 小板裕之, 河野 正：透析患者に deferoxamine 使用後発 症した心臟ムーコル症. 腎と透析 24: 865-870, 1988.

83）近藤順義, 品田 純, 平井三郎, 山本記顯, 吉村博邦, 石 原＼cjkstart昭：急性リンパ性白血病に合併した肺ムーコル症の 1 切除例. 日胸外会誌 $37: 734-737,1989$.

84）有薗健二, 福井博義, 三浦 洋, 早野恵子, 大塚陽一郎, 田尻宗城：Deferoxamine（DFO）治療後に脳型ムーコ ル症を呈した透析患者の 1 例. 日腎誌 31: 99-103，1989.

85）鶴田良成，中根一憲，宮崎高志，臼田正恒，大林祥悟，成 田真康, 柳生宏司, 前田憲志：Deferoxamine使用後, 大動 脈ムーコル症を発症した透析患者の 1 例. 日腎誌 31 : 1345, 1989.

86）長江大介, 馬場廣太郎, 後藤治典, 古内一郎：副鼻腔么一 コル症の 1 例. 耳喉頭頝 61: 201-205，1989.

87）石田 稔, 野入輝久, 田矢直三, 神畠俊子, 神野逸郎, 吉 原 渡, 荻野 敏：鼻副鼻腔ムーコル症例. 日耳鼻 92 21-27, 1989.

88) 木村雅友，下戸 隆，丹司 紅，酒谷邦安：両心室壁在真 菌血栓を呈した全身性ムーコルの1剖検例. 日病会誌 79: $148,1990$.

89）林 明俊, 牧野浩二, 森満 保, 井出 稔: Rhinocerebral mucormycosis の一症例と文献的考察. 日耳鼻 93: 2014-2021, 1990.

90）辻 幸太, 田中 泉, 豊田秀樹, 岡 宏次, 中瀬一則, 伊 藤 質, 宮西永樹：造血器腫瘍に併発した真菌性肺炎に ついての検討. 山田赤十字病院誌 11：76-80，1990.

91）山本宏司, 渡辺尚吉, 黒田練介, 若松時夫, 竹内克呂, 阿 部庄作，本間仗价，平田 保：異常分岐気管支に発生し た菌球型肺ムーコル症の 1 例. 日胸 49: 349-352，1990.

92）千葉直彦, 三木礼子 : カニングハメラ感染症. Jpn J Clin Pathol 38: 1219-1225, 1990.

93） a). 岩津都希雄, 宇田川俊一, 千葉直彦, 三木礼子:急性 骨髄性白血病に合併した Cunninghamella 感染症の 1 例. 真菌誌 30: 45, 1989 .

93) b). Iwatsu $T$, Udagawa $S$, Norizuki $K$, Chiba $N$, Miki R.: Cunninghamella bertholletiae recovered from human disseminated zygomycosis in Japan. Trans Mycol Soc Japan 31: 259-270, 1990.

94) Yagihashi S, Watanabe $K$, Nagai $K$, Okudaira M: Pulmonary mucormycosis presenting as massive fatal hemoptysis in a hemodialytic patient with chronic renal failure. Klin Wochenschr 69: 224-227, 1991.

95）楠 哲夫, 渡辺 仁, 吉田禮子, 孝田雅彦, 本田光弥, 笹 部哲生：ホジキン病に合併した眼窩真菌症の 1 例. 眼紀 42: 1250-1253, 1991.

96) Kutsuzawa T, Matsuura Y, Sakuma H, Narimatsu H, Ohta Y, Yamabayashi H: Multiple pulmonary nodules caused by zygomycosis in a patient without predisposing factors. Jpn J Med 30: 435-437, 1991.

97）洲鎌盛一，山根雅昭，柳下 章，田邊 等 : 慢性発作性頭 痛，無菌性髄膜炎を呈したムーコル症性蝶形骨洞炎の CT ・ MRI. 神経内科 34: 297-300, 1991.

98) Kaneko $T$, Abe F, Ito $M$, Hotchi $M$, Yamada $K$, Okada Y: Intestinal mucormycosis in a hemodialysis patient treated with deferrioxamine. Acta Pathol Jpn 41: 561-566, 1991.

99）福田正高：生前, 胸水培養よりムーコル菌が検出された 急性骨髄単球性白血病の一例. 真菌誌 33: 525-531, 1992.

100）大出尚郎，鴨下 泉，小川葉子，劉 文玲：眼症状を伴っ た鼻脳ムーコル症の1例. Folia Ophthalmol Jpn 43: 507-511, 1992.

101) Harada $M$, Manabe $T$, Yamashita $K$, Okamoto $N$ : Pulmonary mucormycosis with fatal massive hemoptysis. Acta Pathol Jpn 42: 49-55, 1992.

102）三澤真人，大江与喜子，甲斐俊朗，原宏，上野雄司, 植松邦夫：重症血液疾患に合併したムーコル症の 2 症 例. 臨血 33: 1521，1992.

103）飯塚高浩, 稲福徹也, 畑 隆志, 坂井文彦, 神田 直, 田 崎義昭：くも膜下出血を合併した mucormycosis の 1 例. 日内会関東地方会抄録集 3: 68，1992。

104）塩澤伸樹, 稲葉 鋭, 伊藤 誠, 発地雅夫, 久米田茂喜： 健常者に発症し, 組織学的に特異な像を呈した孤立性肺 ムーコル症の 1 手術例. 真菌誌 33: 37-45, 1992.

105）実村 信, 松本 学, 院去万寿子, 山本俊行：急性骨髄 性白血病に続発した Rhizopus pusillusによる肺型ムーコ ル症の 1 例. 医学検査 41: 1440-1445, 1992.

106）加藤治子, 山下えり子, 藤野由美, 徳弘英生 : 肺ムーコ ル症を合併し肺切除術を行った急性リンパ性白血病の一 例. Jpn J Med Mycol 34: 381-384, 1993.

107）佐々木安津子, 塚口真知子, 高安 健, 花井 淳: 骨髄異 形成症候群から移行した急性白血病に胃ムーコル症のみ られた剖検例. Jpn J Clin Pathol 41: 1054-1058, 1993.

108）松村輔一, 渋谷丈太郎, 小林俊介, 半田政志, 近藤 丘, 藤村重文 : 気管支鏡下生検で術前診断された慢性肺ム一 コル症の 1 例. 胸部外科 46: 891-894, 1993.

109）林 英憲, 増田 環, 林 亜紀, 政岡則夫, 上野脩幸, 岸 本誠司, 片岡英幸, 大朏祐治, 園部 宏: 眼窩内容除去術 を行った眼窩ムーコル症の 1 例. 眼紀 44: 1193-1199, 1993.

110）山中 盾, 馬越知浩, 籾山安弘: 糖尿病に合併したム一 コル症の 1 例. 神奈川医会誌 20: 290，1993.

111) Ochiai $H$, Iseda $T$, Miyahara $S$, Goya $T$, Wakisaka $S$ : Rhinocerbral mucormycosis; case report. Neurol Med Chir (Tokyo) 33: 373-376, 1993.

112）高橋由美子, 柳沢高道, 櫻井一成, 浦出雅裕, 吉岡 済: 上顎洞に見られたムーコル症と思われる 1 例. 日口外 誌 39: 61-63, 1993.

113）福代良一, 北村清隆, 池田真康, 熊谷武夫, 岡田 正, 奥 野史郎：皮膚病変を伴った全身性ムーコル症. 稀ではあ 
るが典型的な皮膚真菌症, 第37回日本医真菌学会総会組 織委員会編集・出版, 1994, p.109-112.

114）徳田宇弘, 斧 康雄, 西谷 肇, 青木ますみ, 山内俊一, 国井乙彦, 宮下英夫 : 真菌（ムーコル）性脳動脈瘤の 1 剖検例. 感染症誌 69: 438-443, 1995.

115）鳥井郁子, 原田孝之, 中野晃伸, 長崎真琴, 森川 茂, 古 家寛司：急性前骨髄球性白血病の維持療法中喀血により 死亡した限局性肺ならびに大動脈ムーコル症の 1 剖検 例. 病理と臨床 13: 265-269, 1995.

116）前田泰孝, 赤木功人, 安部倉 信, 朴 憲一, 大津谷耕 一, 木本絹子, 奥 憲一: Rhinocerebral phycomycosis の 1 例. 脳神経外科 23: 521-525, 1995.

117）菅野秀宣, 山中英樹, 坂東邦秋, 籾井安弘, 宮岡 誠: Rhinocerebral mucormycosisによる brain abscess. Jpn J Neurosurg 4: 421-424, 1995.

118）中山 俊, 山本雅之, 李 鐘太, 福島俊洋, 通山 薰, 上 田孝典, 中村 徹, 法木左近, 今村好章: SLE の経過中 に Hemophagocytic syndrome を発症し, T細胞リンパ腫 および Mucor ・ Cytomegalovirus 感染症を認めた一例. 日網会誌 35: 139，1995.

119）奥宮清人, 松林公蔵, 和田知子, 大橋康史, 土居義典：脳 膿瘍を併発した鼻脳ムーコル症の 1 治験例. 老化と疾 患 8: 1801-1805, 1995.

120）児玉 章, 花満雅一, 望月 隆, 田中 寛, 北嶋和智：鼻 脳型ムーコル症の一例. 日鼻科会誌 34: 234, 1995.

121）森 朗子, 細川朋子, 深美 悟, 豊田由香, 馬場廣太郎： 脳神経麻痺を伴った鼻脳ムーコル症の 1 例. 日鼻科会 誌 34: 235, 1995.

122) Funada H, Matsuda $T$ : Pulmonary mucormycosis in a hematology ward. Intern Med 35: 540-544, 1996.

123）佐々木 津, 山崎悦子, 植田誠司, 吉田道彦, 加藤和伸, 田村智彦, 田辺寿一, 原野 浩, 小川浩司, 松崎道男, 毛 利博, 蒲田康広, 北村 均, 大久保隆男 : ムーコルに よる急性虫垂炎を発症した重症再生不良性貧血；1 剖検 例. 臨血 37: 152-157, 1996.

124）関谷栄規, 鈴木重成, 森 朗子: 眼症状を伴った鼻脳 ムーコル症の 1 例. 眼臨 90: 641-644, 1996.

125）山口昭彦, 北林 淳, 高津 洋, 安宅芳春 : ムーコル血 栓を心室内に認めた不応性貧血の1例. 日常診療と血 液 6: 818-822, 1996.

126）戸島洋一, 徳留隆博, 大塚十九郎: 糖尿病, 肝硬変を基 礎疾患とし，肺結核遺残空洞に発症した慢性肺ムーコル 症の 1 例. 日胸疾会誌 35: 100-105, 1997.

127）村守史彦，木下寛也，小林克治，福谷祐賢，宮津健次，林 真弘, 青木達之, 三浦裕次, 原田憲一, 越野好文: 急性骨 髄性白血病で骨䯣移植後, ムーコル菌と単純ヘルペスウ イルス 2 型の混合感染を起こした 1 剖検例. 脳神経 49: 449-453, 1997.

128）大西浩介, 河本 俊, 加藤正仁, 国分武彦, 飯尾光博：脳 梗塞をきたしたムーコル鼻脳症の1 例. 苫市病 11: 43$47,1997$.

129）源馬 均, 小野貴久, 増田昌文, 中野桂子, 上村桂一, 渡 辺健次, 豊嶋幹生, 須田隆文, 千田金吾, 佐藤篤彦, 中村 浩淑，西村和子：Rhizopus microsporus var, rhizopodiformis によるアレルギー性気管支肺真菌症の 1 例. アレルギー の臨床 17: 928-931，1997.

130）獅子原孝輔, 亀井克彦, 江渡秀紀, 栗山喬之, 西村和子, 宮治 誠: ステロイド服用中の紅皮症患者に発症した Cunninghamella bertholletiaeによる肺ムーコル症の 1 例一 特にCunninghamella bertholletiae の診断について一。呼
吸 16: 967-971, 1997.

131）橋口浩二，二木芳人，宮下修行，黒木昌幸，中島正光，川 根博司, 松島敏春, 西村和子：Cunninghamella bertholletiae 肺感染症の 1 例. 感染症誌 71: 264-268, 1997.

132) Kitabayashi A, Hirokawa M, Yamaguchi A, Takatsu $\mathrm{H}$, Miura AB: Invasive pulmonary mucormycosis with rupture of the thoracic aorta. Am J Hematol 58: 326-329, 1998.

133）梅村 淳, 鈴鹿知直 : 眼窩尖端症候群を呈したRhinocerebral mucormycosis の1例. 脳神外科 26: 439-442, 1998.

134）橋本俊彦, 有馬和彦, 菊池仁志, 岩城 徹, 木下義晶, 酒 井浩徳, 梅田文夫, 名和田 新: 海綿静脈洞内ムーコル 菌感染症により眼虚血症候群, 多発脳神経麻痺をきた し，クモ膜下出血にて死亡したインスリン非依存性糖尿 病の 1 剖検例. Diabetes J 26: 73-77, 1998.

135）西成民夫，黒木 淳，西村茂樹，中鉢明彦，三浦 亮： ムーコル症による肺塞栓で死亡した重症再生不良性貧血 の 1 剖検例; 二次性へモクロマトーシスおよび鉄除去剤 との関連. 臨血 39: 1142, 1998.

136）原裕子：浸潤性肺ムーコル症（photo quiz)。小児診 療 9: 1583-1585, 1998.

137）川上譲治，武藤壽孝，内田暢彦，金澤正昭，大内知之，賀 来 亨：上顎洞ムーコル症の1例. 日口外誌 44: 592594, 1998.

138）仙崎英人, 植村芳子, 水岡 寛, 山本大悟, 義澤克彦, 中 川安之, 上田 恵, 螺良英郎：ムーコル塞栓を両心室内 にみた, deferrioxamine 投与を受けていた不応性貧血の 一剖検例一ムーコル症と鉄代謝, deferrioxamine の関連 性について. 病理と臨床 17: 981-985, 1999.

139) Kawai H, Hasegawa M, Hagiwara S, Shimizu H: Lethal junctional epidermolysis bullosa showing mild blister at birth. Pediatr Int 41: 571-574, 1999.

140）松本 勲, 新谷博元：健常人に発症し, 囊状気管支拡張 を呈した肺ムーコル症の1例. 気管支学 21: 418-422, 1999.

141）堀越淑子，難波克彦：片眼の眼球突出を来たし急激な死 の転帰をとった 1 例. 眼臨 93: 408-410，1999.

142）松浦 久, 星野恵津夫, 大林隆晴, 大瀬 亨, 杉山 肇, 茂木秀人, 鈴木大介, 山内俊一, 藤森 新, 山中正巳, 安 田寛基, 山口英世 : ムーコルに伴う S 状結腸の縦走潰瘍 を認めた糖尿病の一剖検例. 帝京医誌 22: 89-95, 1999.

143）川越宣明, 新井幸宏, 新井ほのか, 田所治朗, 半田智幸, 井上史央, 中村祐子, 青柳有名, 廣田 健, 青柳正邦, 中 村裕一, 斉藤憲治, 古沢新平： CT 上空同性病変を認め, 剖検にて肺ムーコル症と診断された急性骨髄性白血病. Dokkyo J Med Sci 26: 301-305, 1999.

144）牧野知大, 柳 富子, 遠山純子, 山田春木, 瀬田克孝, 三 浦恭定, 北村成大：汎発性ムーコル症に合併した hemophagocytic syndromeにより多臟器不全で死亡した糖尿 病の 1 例. 日内会誌 88:133-134, 1999.

145）大野道也，小田 寛，大橋宏重：デフェロキサミンによ るへモジデローシス治療中にムーコル症を合併した高齢 血液透析患者の 1 例. 最新医学 54: 1788-1789, 1999.

146）森 俊明, 宗宮 基, 内山公子, 古屋寛司, 加藤 譲 : ムーコル症による右肺動脈内塞栓を認めた骨髄異形成症 候群 (MDS) の1例. 島根医学 19: 34-39, 1999.

147）和泉典子, 熊谷浩昭, 新藤徹郎：寛解期に肺ムーコル症 による胸部下行大動脈穿破をきたし，喀血死した急性骨 髄性白血病の剖検例．臨血 41: 1201-1207, 2000.

148）宮田泰彦, 梶口智弘, 斉藤 稔, 竹山英夫：Deferoxamine 
使用中にムーコル症による動脈血栓を生じた再生不良性 貧血から骨髄異形成症候群への移行例. 臨血 41: 129134, 2000.

149）古市祥子, 高橋典明, 庄田利明, 丸岡秀一郎, 林 伸一, 大森千春, 赤柴恒人, 堀江孝至 : 気管支鏡下肺生検で診 断しえた肺ムーコル症の 3 例. 気管支学 22: 109-114, 2000.

150）寺田秀夫：慢性骨髄単球性白血病の 1 例, MDS か MPD か？血液フロンティア 10: 1454-1461, 2000.

151）牧田あずさ, 横㴊宗秀, 田中雄一郎, 井上あい, 日比野美 治, 水村幸之助：Rhinocerebral mucormycosis が原因之 考えられた眼窝尖端部症候群の 1 例. 眼科 42: 855-859, 2000 .

152）小浦方啓代，田邊嘉也，三上 理，佐藤和弘，富樫賢一, 菅原正明，宮村治男，佐藤良智：長岡赤十字病院におけ る肺真菌症についての検討. 長岡赤医誌 13: 51-55, 2000

153）伊藤友浩, 岡戸丈和, 田中啓之, 田村博之, 秋葉 隆, 丸 茂文昭, 樋口晃司, 小山信之: 透析患者に発症した肺 ムーコル症の1例. 日本透析会誌 34(suppl 1): 841 , 2001.

154）馬庭 厚, 田中栄作, 田口善夫, 種田和清, 井上哲郎, 加 藤晃史, 櫻木 稔, 前田勇司, 寺田邦彦, 相原雅典 : 気管 支喘息患者に急激に発症し進行した Rhizopus microsporus var. rhizopodiformis 肺感染症の 1 例. 感染症誌 76: 396399, 2002.

155）木村雅友, 酒谷邦康, 吉田朋子, 橋本重夫：厚膜分生子 形成を認めた気管支内接合菌症. Acta Pathol Jpn 90: 352, 2001.

156) Yamauchi $T$, Misaki $H$, Arai $H$, Iwasaki $H$, Nakai $\mathrm{H}$, Ueda $\mathrm{T}$ : An autopsy case of disseminated mucormycosis in a neutropenic patient receiving chemotherapy for the underlying solid malignancy. J Infect Chemother 8: 103-105, 2002.

157）西村良成, 吉田知広, 岡島道子, 前馬秀昭, 和田英男, 高 桑 聖, 上原貴博, 犀川太, 小泉晶一: 非血縁者同種 幹細胞移植後ムーコルによる冠動脈塞栓により死亡した MDS の 1 剖検例. 日览誌 106: 780, 2002.

158）冨田尚吾, 武田純一, 山下 潤, 鍵山奈保, 蓮本 誠, 松 石 純, 斉藤郁子, 貴嶋宏全, 倉石 博, 菊池敏樹, 大塚 英彦，成島道昭，鈴木 - : 特異な気管支鏡所見を呈し た気管支内ムーコル症の 1 例. 第 3 回真菌症フォーラム 抄録集, p.91, 東京, 2002 .

159）大橋洋綱, 渡辺健太郎, 菊池隆秀, 北原光夫, 折笠英紀 : 子宮癌肉腫に対する化学療法中ムーコル症による真菌性 塞栓症を合併した一例. 第 3 回真菌症フォーラム抄録 集, p.92, 東京, 2002 .

160）財前行宏, 大津達也 : 経気管支肺生検で診断され, アム
フォテリシン B が著効した肺ムーコル症, 第 3 回真菌症 フォーラム抄録集, p.93-95, 東京, 2002.

161）森健, 土屋輝余子, 江頭元樹, 高橋まゆ夕, 小原共 雄, 宮崎忠博, 押味和夫, 小栗豊子, 一戸正勝 : 急性リン パ性白血病に合併した Cunninghamellaによる感染症. 第 3 回真菌症フォーラム抄録集, p.96-97, 東京, 2002.

162）池本秀雄, 奥平雅彦：シンポジウム; Phycomycosis（い わゆるムーコル症). 真菌誌 19: 25-30, 1978.

163) Kontonyiannis DP, Wessel VC, Bodey GP, Rolston KVI: Zygomycosis in the 1990's in a tertiary-care cancer center. Clin Infect Dis 30: 851-856, 2000.

164) Abe $F$, Inaba $H$, Katoh $T$, Hotchi $M$ : Effect of iron and deferrioxamine on Rhizopus infection. Mycopathologia 110: 87-91, 1990.

165) Irwin RG, Rinaldi MG, Walsh TJ: Zygomycosis of the respiratory tract. In Fungal diseases of the lung. (Sarosi GA, Davies SF ed, 3rd edition) p.163-185, Lippincott Williams \& Wilkins. Philadelphia, 2000.

166) Johnson EM, Szekely A, Warnock DW: In-vitro activity of voriconazole, itraconazole and amphotericin $\mathrm{B}$ against filamentous fungi. J Antimicrob Chemother 42: 741-745, 1998.

167) Wildfeuer A, Seidl HP, Paule I, Haberreiter A: In vitro evaluation of voriconazole against clinical isolates of yeasts, moulds and dermatophytes in comparison with itraconazole, ketoconazole, amphotericin B and griseofulvin. Mycoses 41: 309-319, 1998.

168）森健：造血器悪性腫瘍における抗真菌剂の投与と問 題点. 真菌誌 40: 143-149, 1999.

169) Wingard JR: Lipid formations of amphotericins; are you a lumper or a splitter? Clin Infect Dis 35: 891895, 2002.

170) Walsh TJ, Hiemenz JW, Seibel NL, Seibel NL, Perfect JR, Horwith G, Lee L, Silber JL, DiNubile MJ, Reboli A, Bow E, Lister J, Annaissie EJ: Amphotericin B lipid complex for invasive fungal infections; analysis of safety and efficacy in 556 cases. Clin Infect Dis 26: 1383-1396, 1998.

171) Dignani MC, Anaissie EJ, Hester JP, O'Brien S, Vartivarian SE, Rex $\mathrm{JH}$, Kantarjian $\mathrm{H}$, Jendiroba DB, Lichitiger B: Treatment of neutropenia-related fungal infections with granulocyte colony-stimulating factor-elicited white blood cell transfusions; a pilot study. Leukemia 11: 1621-1630, 1997.

172) Weng DE, Wilson WH, Little R, Walsh TJ: Successful medical management of isolated renal zygomycosis; case report and review. Clin Infect Dis 26: 601-605, 1998. 


\title{
Zygomycosis: Two Case Reports and Review of Reported Cases in the Literature in Japan
}

\author{
Takeshi Mori ${ }^{1)}$, Motoki Egashira ${ }^{1)}$, Norihiko Kawamata ${ }^{1)}$, \\ Kazuo Oshimi ${ }^{1)}$, Kazuhiro Nakamura ${ }^{2)}$, Toyoko Oguri ${ }^{3)}$, \\ Hideko Aida ${ }^{4)}$, Akiko Hiruma ${ }^{5)}$, Masakatsu Ichinohe ${ }^{6)}$
}

${ }^{1}$ Division of Hematology, Department of Internal Medicine, Juntendo University School of Medicine, 2-1-1 Hongo, Bunkyo-ku, Tokyo 113-8421, Japan

${ }^{2}$ Second Department of Pathology, Juntendo University School of Medicine, 2-1-1 Hongo, Bunkyo-ku, Tokyo 113-8421, Japan

${ }^{3}$ Clinical Laboratory of Juntendo University Hospital, 3-1-3 Hongo, Bunkyo-ku, Tokyo 113-8431, Japan

${ }^{4}$ Department of Nursing, Juntendo University Hospital, 3-1-3 Hongo, Bunkyo-ku, Tokyo 113-8431, Japan

${ }^{5}$ Juntendo University Library,

2-2-26 Hongo, Bunkyo-ku, Tokyo 113-0033, Japan

${ }^{6}$ Department of Nutrition, Tokyo Kasei University,

1-18-1 Kaga, Itabashi-ku, Tokyo 173-8602, Japan

This article reports two cases of zygomycosis and analyzes the zygomycosis cases reported in the literature in Japan.

Case 1 was a 43-year-old male with malignant lymphoma who presented complications of pneumonia and cerebral bleeding, leading to his death. Autopsy findings showed pulmonary lesions were due to zygomycosis. Cerebral lesion was presumed to be due to zygomycosis without pathological examination. Case 2 was a 52-year-old male with acute lymphocytic leukemia from whom 4 sputum cultures were taken that were positive for Cunninghamella elegans. Combination therapy of itraconazole and amphotericin B (AMPH) was begun, and AMPH was changed to liposomal amphotericin B. During the neutropenic period after receiving premedication for a peripheral blood stem cell transplantation performed for his underlying disease, high fever was recognized and Staphylococcus epidermidis was isolated from the blood culture. Despite the change in antibiotics administered, pneumonia also developed as a complication, causing his death.

Two hundred four cases of zygomycosis have been reported in the literature in Japan:55 cases were rhinocerebral zygomycosis, including 29 cases with no underlying disease. A premortem diagnosis was made in 34 cases by pathological findings of operation materials or drainage samples, and 24 cases were postmortem.

Pulmonary, disseminated, cardiovascular, gastrointestinal and thyroidal zygomycoses were found in 144 cases, including 66 cases with leukemia. A premortem diagnosis was made in 39 cases and 120 cases were postmortem.

Prognosis of rhinocerebral type was better in operated or drainage cases, and for resected cases in all other types.

Five cases with allergic zygomycosis were all alive.

There were only 14 cases in which isolated fungi were identified (Cunninghamella spp. from 5 cases, Mucor spp. from 2, Rhizomucor spp. from 2, and Rhizopus spp. from 5). 